\title{
ETNOARQUEOLOXÍA E MICROHISTORIA DUNHA PAISAXE CULTURAL: A PARROQUIA DE SAN PEDRO DE CEREIXA (POBRA DE BROLLÓN, LUGO)
}

\author{
XURXO M. AYÁN VILA
}

\begin{abstract}
Resumen
Este artigo recolle a análise arqueohistórica do proceso de conformación dunha paisaxe cultural a escala local, como é a parroquia de S. Pedro de Cereixa (Pobra de Brollón, Lugo). Partindo da Arqueoloxía da Paisaxe reconstruímo-las diferentes estratexias de construcción do espacio social empregadas polas sucesivas formacións socioculturais que ocuparon a zona dende a Prehistoria Recente deica a actualidade. $\mathrm{Na}$ segunda parte achegámonos ó patrón de racionalidade manexado pola comunidade campesiña que construíu e dotou de sentido á paisaxe rural tradicional.

Para acadar este obxectivo, desenvolvemos unha aproximación interdisciplinar coa angueira de maximizar tanto as aportacións de diferentes tendencias historiográficas (Historia Rural, Antropoloxía Histórica, Microhistoria) como a potencialidade da utilización conxunta de diversas ferramentas metodolóxicas, nomeadamente o baldeirado de fontes documentais secundarias, a enquisa etnográfica, a análise iconográfica e a Historia Oral.
\end{abstract}

\section{Palabras Clave}

Arqueoloxía da Paisaxe; Etnoarqueoloxía; Microhistoria; Antropoloxía Cultural; Historia das Mentalidades; Relixiosidade popular.

\begin{abstract}
From the point of view of Landscape Archaeology we try to show the genealogy and development of a cultural landscape in a galician little village.

Our research definies several spatial patterns built by the different societies which inhabited the area of San Pedro de Cereixa from the Recent Prehistory to nowdays.

In the second part of our research we get inside the mental universe of the traditional peasant community who endowed this landscape with sense.

This cosmovision is not a static model but a cultural product of a historical process that embraces a mixture of continuities and ruptures, popular believes and the imposition of a official religion and a civilization of customs by the Church.
\end{abstract}

\section{Key Words}

Landscape Archaeology, Ethnoarchaeology, Microhistory, Cultural Anthropology. 
Porque a etnografia está nun perigo gravisimo e a xente non se dá conta deste perigo. Un castro ou as ruinas dunha vila romana, por exemplo, se non se escavan hoxe, escávanse dentro de cincuenta anos, as cousas están ali soterradas, esas xa non se perden. En cambio as cousas que o pobo usa, que vai desbotando, esas desaparecen. Xaquín Lorenzo (1976)

\section{INTRODUCCIÓN}

A cita que encabeza o presente traballo non vén sendo unicamente unha mera referencia introductoria senón que serve, por unha banda, de homenaxe neste Ano Xocas ó labor polifacético levado a cabo polo etnógrafo, arqueólogo e historiador Xaquín Lorenzo, e por outra, fornece unha síntese da perspectiva asumida na nosa investigación. Neste senso, o texto que expoñemos é o resultado dunha liña de traballo que, partindo da disciplina arqueolóxica, precura levar a cabo un estudo a escala microspacial, etnoarqueolóxica e interdisciplinar, da paisaxe rural tradicional. A este respecto, considerámonos debedores da tradición etnográfica chantada e desenvolvida por unha manchea de investigadores e intelectuais, primeiro como membros do Seminario de Estudios Galegos, e posteriormente do Instituto de Estudios Galegos Padre Sarmiento.

Como arqueológo que desenvolve o seu traballo de investigación nesta última institución, considero prioritario reivindicar e louvar criticamente esa traxectoria que deixou unha fonda pegada nas Ciencias Sociais do noso país. A obra desenvolta e o enfoque asumido por autores como F. López Cuevillas, F. Bouza Brey, V. Risco, X. Lorenzo, X. Taboada Chivite ou A. Fraguas conduciu a un estreito achegamento entre Antropoloxía Cultural, Etnografía e Arqueoloxía, sen parangón no contexto peninsular. Esta liña de traballo deu como resultado, por exemplo, que Galicia conte co corpus máis amplo de folklore vencellado a xacementos arqueolóxicos ou que a sociedade rural tradicional, a nosa cultura popular, fose considerada como obxecto a estudiar dende unha aproximación humanística integral.

De feito, a nosa pescuda sobre unha parroquia galega concreta, recolle o enfoque historiográfico que deu ó prelo unha serie de monografías locais de carácter interdisciplinar sobre diferentes enclaves parroquiais como é o caso de Castro Caldelas (Risco 1927), Vilar de Ortelle, Pantón, Lugo (Castro López 1929), a vila de Calvos de Randín, Ourense (López Cuevillas e Lorenzo Fernández 1930), parroquia de Velle (López Cuevillas, Fernández Hermida e Lorenzo Fernández 1936), Santa Marta de Moreiras (Fernández Oxea 1968), ou Bamiro en Vimianzo (Lema Suárez 1977). 
Nembargantes, cómpre encetar unha anovación teórico metodolóxica deste tipo de aproximacións, que sen dúbida foron o resultado dun contexto historiográfico moi concreto (Ayán e Ameixeiras 2002, Mandianes Castro 2003) e dunha perspectiva local, criticada polo seu carácter extremadamente microhistórico, que se enfrontaba á tendencia desenvolta dende a década de 1960 polos historiadores marxistas e da Escola dos Annales francesa, dunha Historia Estructural conducente á consecución de estudos globais e sínteses xerais sobre os procesos e períodos históricos.

Pola nosa banda, cremos que o camiño para unha fértil reorientación da tradición citada, debe abrirse no seo dunha encrucillada na que conflúan, dunha banda, a Arqueoloxía da Paisaxe (Criado 1999) e, doutra banda, a Antropoloxía histórica, a Historia das mentalidades e a Microhistoria consolidadas no contexto historiográfico europeo nas últimas décadas como resultado do achegamento entre a antropoloxía estructuralista e a alcumada terceira xeración da Escola dos Annales (Barros 1993).

\section{MARCO TEÓRICO-METODOLÓXICO DO TRABALLO}

En consoancia co exposto anteriormente, a liña de investigación seguida neste estudo vencella intimamente a problemática arqueolóxica do Noroeste e maila colaboración e interdisciplinariedade entre Arqueoloxía Rural, Arqueoloxía da Paisaxe e Antropoloxía Cultural, dando lugar a un traballo de síntese sobre a xenealoxía e evolución histórica do espacio rural tradicional galego con resultados complementarios e perfectamente aproveitables por parte desas tres disciplinas (Criado 1991, 1993; Criado et al. 1998; Criado e Ballesteros 2002, Candal 1993, Arizaga 2002).

Imos contrastar a rendabilidade desta estratexia de investigación interdisciplinar levando a cabo unha deconstrucción arqueolóxica (dende o presente) dunha paisaxe cultural a escala microespacial para chegar, mediante unha reconstrucción diacrónica da mesma, ó coñecemento do desenvolvemento histórico que desembocou e deu lugar a esa paisaxe que percibimos actualmente coma unha entidade formal, unha ruína arqueolóxica, cargada de sentido. Tentaremos reconstruír como se percibiu historicamente, como se construiu culturamente o espacio da actual parroquia de Cereixa, conformada no último milenio dacordo cun patrón de racionalidade en vías de desaparición, vencellado intimamente a unha sociedade rural tradicional, á que nos achegamos hoxendía como arqueólogos e antropólogos. 
Partimos dun concepto de paisaxe coma un producto socio-cultural creado pola obxectivización, sobre o medio e en termos espaciais, da acción social tanto de carácter material coma imaxinario, coma unha realidade multidimensional: ambiental, social, simbólica, cultural e perceptiva (Criado e Villoch 1998: 64-5; Criado 1999: 5). Esta noción supera a consideración formalista do espacio como algo que vén xa dado, coma unha realidade estática de orde física e ambiental, permitíndonos considera-la realidade espacial coma unha realidade eminentemente social que se constrúe culturalmente. $\mathrm{O}$ espacio é unha construcción social, imaxinaria, en movemento continuo, enraigada na cultura; porén, existe unha estreita relación estructural nas estratexias de apropiación do espacio entre pensamento, organización social, subsistencia e concepción-utilización do medio ambiente (Criado 1993: 42).

Dacordo con este marco teórico e conceptual, pretendemos abordar unha Arqueoloxía da Paisaxe dunha parroquia da Terra de Lemos, entendéndoa coma unha estratexia de investigación (específica, lexítima e que non invalida nin se contrapón a outras aproximacións diferentes) orientada ó estudio e reconstrucción, con metodoloxía arqueolóxica, dos procesos e formas de culturización ó longo da historia, do espacio no que se asenta a comunidade de Cereixa.

Tratamos en primeiro lugar con entidades arqueolóxicas, restos mudos da cultura material dos que inferi-la actividade social de comunidades pretéritas. A ferramenta metodolóxica empregada será a análise das formas materiais concretas que configuran un determinado patrón de espacialidade nun determinado momento. Esta análise formal do xeito como cada formación sociocultural se implanta no espacio e o dota de sentido, permitirá achegarnos minimamente á estructura organizativa desa paisaxe.

Esta deconstrucción arqueolóxica compleméntase de maneira ricaz á hora de estudia-lo último estadio evolutivo da microhistoria da nosa parroquia, isto é, o artellamento da paisaxe rural tradicional. Neste senso, contamos co privilexio de dispoñer non só de documentación histórica propiamente dita, senón tamén de suxeitos lingüísticos, integrantes vivintes da cultura popular que se analisa, nun momento, o actual, no que está a desaparecer o patrón de racionalidade tradicional. Cómpre botar man da Antropoloxía Histórica, un ámbito de estudo potenciado na década de 1970 como resposta á preponderancia da Historia estructural, que centra a súa atención nos sectores sociais tradicionalmente marxinados pola investigación, remarcando o interese pola análise dos xestos, as formas de sociabilidade, as crenzas relixiosas, o discurso ideolóxico, os ritos que inzan a vida cotiá, os pensamentos, os comportamentos indefinidamente repetidos no seo das comunidades culturais minoritarias do pasado (Le Goff 1985; Burke 1990; Gurevich 1992). 
A antropoloxía histórica, pois, interésase fundamentalmente polo estudio do universo mental das sociedades ó longo da historia, tratando de comprende-las comunidades rurais do pasado, non só por medio da documentación, senón tamén valéndose de paralelos etnográficos que amosan a propia concepción do mundo dun sector social que se presenta mudo nas fontes escritas. Esta tendencia vén sendo unha mostra máis da fragmentación experimentada polo discurso histórico na crise da postmodernidade, froito da asunción dunha perspectiva microhistórica e do consecuente achegamento ás outras ciencias sociais (Burguière 1995).

A este respecto, recoñecemo-lo valor deste enfoque propio da alcumada Microhistoria, tendencia que tenta profundizar nas dimensións simbólicas da acción social mediante unha aproximación a nivel microespacial (Le Roy Ladurie 1981; Ginzburg 2001: 9-28). Para iso válese dun descenso na escala de análise e da utilización dunha descripción densa que maximiza a información aportada por todo tipo de fontes e disciplinas (Geertz 1997: 19-40).

Asemade, contamos coa posibilidade de aborda-lo estudio da cultura material da sociedade rural tradicional, para o que consideramos imprescindible a asunción da alcumada Etnoarqueoloxía ${ }^{1}$ como ferramenta metodolóxica. Esta última disciplina, na súa vertente hermenéutica, postestructuralista e histórica, fornece o marco axeitado para achegármonos a sociedades preindustriais nas que se conta con protagonistas históricos vivos e con cultura material viva (González Ruibal 2003, 2003a). A este respecto, a cultura material está cargada de significación e constitúe un obxecto fundamental para reconstruí-lo patrón de racionalidade dunha sociedade. É un producto cultural destinado a comunicar unha información que é manexada, consciente e inconscientemente, pola comunidade, podendo ser considerado tanto un reflexo coma un xerador activo de conducta social. Cómpre, xa que logo, analisala coma unha entidade viva que desempeña un rol activo na constitución social da realidade. Dende esta perspectiva pode ser abordado o trasfondo social e simbólico que se agocha tralo modelo de espacialidade definido pola sociedade rural tradicional.

\footnotetext{
${ }^{1}$ Reproducimo-la definición de A. González Ruibal (2003a: 12): Etnoarqueología es el estudio arqueológico de sociedades generalmente preindustriales, con el objetivo de producir una arqueología más crítica y menos sesgada culturalmente, de generar ideas que favorezcan el debate arqueológico y de contribuir al conocimiento de las sociedades con las que se trabaja, teniendo en cuenta sus tradiciones, ideas y puntos de vista.
} 


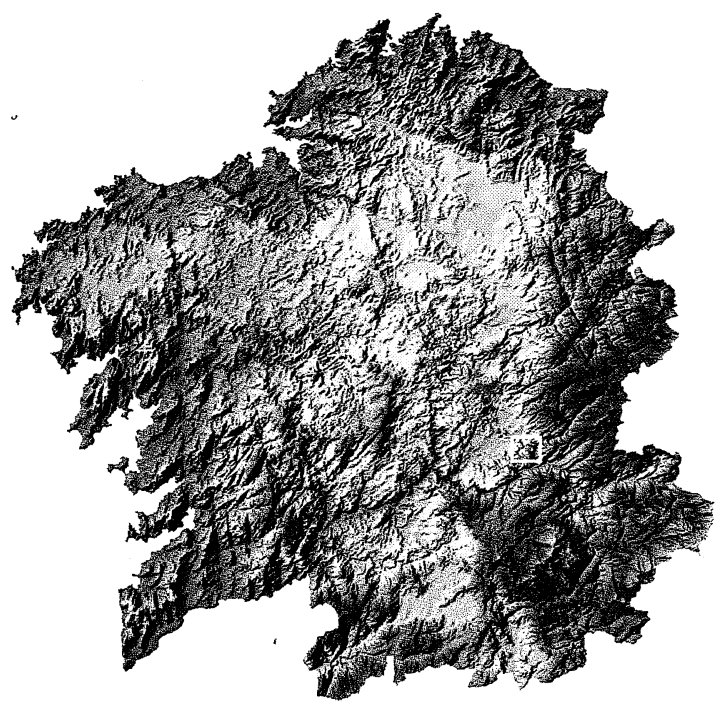

Figura 1.- Ubicación en Galicia da zona de estudio.

\section{O TEMPO: APROXIMACIÓN HISTÓRICAÁ PARROQUIA DE CEREIXA}

Abordaremos a continuación unha reconstrucción arqueohistórica do proceso de ocupación do espacio no que se asenta a actual parroquia de Cereixa, definindo os diferentes modelos de apropiación dese marco medioambiental por parte das diferentes formacións socioculturais que se sucederon dende o Neolítico ata a actualidade.

As diferentes estratexias adoptadas por esas comunidades modelaron ese espacio dando lugar a unha paisaxe concreta que pode ser definida coma un producto humano que emprega unha realidade dada (o espacio físico) para crear unha realidade nova: o espacio habitacional e, por conseguinte, social, ó que se confire un significado simbólico. Dito producto compónse de diferentes entidades formais, que se proxectan espacialmente, son visibles, polo que poden ser apreixadas e descritas pola observación arqueolóxica. A análise formal das relacións espaciais significativas entre as entidades do rexistro, isto é, a estructura espacial, permite achegarnos non só á lóxica espacial dunha determinada comunidade, neste caso ás relacións interespaciais que construíron esas sociedades, senón tamén á propia lóxica social do espacio. Eis que esa estructura espacial sexa o producto dunha sociedade concreta que, por medio dunhas determinadas tecnoloxías espaciais e arquitectónicas, reproduce o patrón de racionalidade imperante. 
Estes modelos de apropiación do espacio tiveron que adaptarse, e modificar á súa vez, un medio físico definido pola bacía baixa do río Saa, afluente do río Cabe.

\section{O espacio medioambiental: a bacía baixa do río Saa}

Antes de amosar minimamente ese ámbito xeográfico concreto, reproduciremos a descripción sobre a parroquia levada a cabo por Pascual Madoz na década de 1840, dende uns posicionamentos economicistas, empiristas e modernos, propios da época, que se baseaban nunha concepción burguesa do espacio como marco para a explotación económica (Madoz 1845: 307). Asemade serviranos de introducción ó marco espacial obxecto de estudio:

S. Pedro de Cereija: feligresía de la provincia y diócesis de Lugo (9 leguas), partido judicial de Quiroga y ayuntamiento de la Puebla del Brollón. SIT. en una hondonada sobre la margen izquierda del río Saa y derecha del arroyo Ramos. CLIMA. Húmedo, pero bastante sano. Tiene unas 70 casas medianas, distribuidas en los lugares de Areas, Aquel-Cabo, Barrio-falcón, Cereija (casa rectoral e iglesia), Cima de Vila, Corbal, Giontiñas, Lende, Nogueiras, Puente, Rairos, Sierra y Zapateira. La iglesia parroquial es capaz y decente. Su curato de primer ascenso y patronato real y eclesiástico. El TERM. se estiende á 1/8 leguas de N a S y 1/4 de E-0. Confina por el $N$ con los de Castrosante y Eijon; al E. con los de Puebla y Castroncelos, al S. Pinel y Chavaga y por el O. Fornelas, comprendiendo los montes de Chá de Monte Mío, Lamas Boas, Penedos do Castro y Santa Bárbara. El TERRENO es tenaz y arcilloso, y en el estío carece de riego, no obstante bañarle el indicado río Saa y los arroyos que en él desagüan, denominados Regueiro y San Lorenzo, Los CAMINOS se hallan poco cuidados, y en ellos se encuentran los puentes de Cereija y Nogueiras y los pontones de Areas y Torrente. El CORREO se recibe por la Puebla del Brollón. PROD. trigo, maíz, patatas, centeno, legumbres, castañas y vino; cría ganado lanar, cabrio, vacuno y de cerdo; hay caza, alguna pesca; molinos harineros, telares, sastres, zapateros y algunos otros oficios. POBL. 63 vecinos y 321 almas. CONTRIBU$Y E$ con su ayuntamiento.

En liñas xerais, a parroquia ( $350 \mathrm{~m}$ s.n.m) establécese nunha unidade morfolóxica ben delimitada como é a bacía baixa do río Saa, vencellada á depresión de Lemos, aínda que separada orograficamente desta pola presencia ó W dunha dorsal que, cunha disposición NW-SE, se define pola Serra do Moncai (526 m), a Serra de Lamas (531 m) e A Costa (449 m). Polo N sitúase unha serie de pequenos outeiros: Mompedroso (402 m), A Coroa/O Castro (416 m), A Lucenza, O Carpancedo e San Lourenzo (402 m). Esta pequena estribación montesía serve de transición en- 
tre a planicie do val do Saa e maila penichaira da Cha de Castrosante (420-440 m), que se estende entre os cursos dos ríos Cabe (W) e Saa (SE-E).

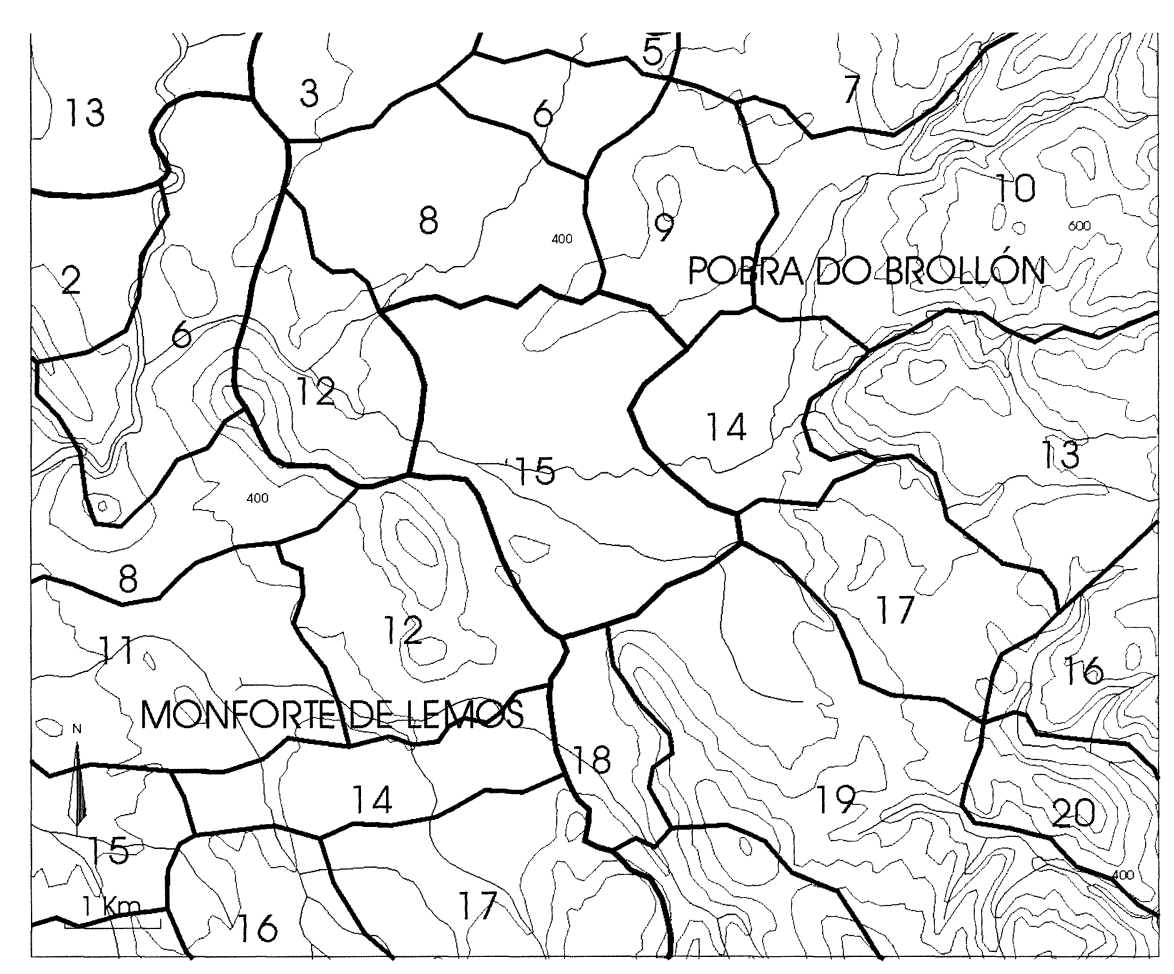

8. San Xurxo de Eixón. 9: Santa Mariña de Castrosante. 12: Santa Comba de Fomelas. 14: San Pedro da Pobra de Brollón. 15: San Pedro de Cereixa. 17: Santiago de Castroncelos. 18: Santa María de Pinel. 19: San Xoán da Brence.

12) San Xoán de Chavaga (concello de Monforte de Lemos).

Figura 2.- Delimitación parroquial da zona.

O clima é oceánico continental, con temperaturas suaves (14 grados de media anual), invernos fríos con abundancia de xeadas e veráns calurosos. No tocante á vexetación predomina nas zonas de monte o piñeiral e o mato de tipo arbustivo (xestas, piornos, carqueixas, toxos, fentos e silvas), mentres no val aínda se conserva o bosque de ribeira á carón do Saa e regatos asociados (amieiros, chopos, salgueiros), algunhas carballeiras e soutos así como árbores frutais (mazairas, figueiras e cerdeiras). 
O tipo base de solo nesta pequena depresión é o pseudoglei, cunha rocha nai de sedimentos arxilosos terciarios. Posúe unha drenaxe interna deficitaria, aparecendo no primeiro nivel $(0-10 \mathrm{~cm})$ gravas e cuarcita converténdose nos niveis máis profundos $(60 \mathrm{~cm})$ en sedimentos arxilosos e gravillosos, con predominio de cores vermellas e verdes (Guitián 1974). Estas características edafolóxicas condicionaron en grande medida a evolución da paisaxe da zona en catro aspectos fundamentais:

- En primeiro lugar, os depósitos terciarios de natureza arxilosa da bacía do Saa sufriron procesos de sedimentación no Mioceno, conformando xacementos aluviais ou secundarios cunha grande riqueza aurífera, o que explicará a súa explotación intensiva trala conquista romana.

- Pola súa banda, estes terreos arxilosos complicaban notablemente a súa drenaxe, o que obrigou á realización dunha complexa rede arquitecturizada (represas, canles, etc.) para acadar unha correcta irrigación e adaptación para o cultivo intensivo dos solos profundos e máis fértiles do val do Saa.

- Este marco xeolóxico e edafolóxico condicionou dende a Idade do Ferro a arquitectura local, xa que se empregaron como materiais constructivos os abondosos coios de cuarcita e a arxila como argamasa para o levantamento de muros de mampostería, como así o amosa o lugar coñecido como $A s$ Pozas do Barro, espacio utilizado tradicionalmente para a extracción de arxila.

- Finalmente, a calidade dos sedimentos arxilosos e areosos do terreo fomentou a súa explotación intensiva nas década de 1970 mediante a apertura de canteiras -abandonadas a comezos dos anos 80- nos outeiros septentrionais anteriormente citados, actividade extractiva que produciu afeccións notables en xacementos arqueolóxicos como $A$ Coroa/O Castro ou o Castro da Lende/San Lourenzo).

\footnotetext{
${ }^{2}$ Sebastián Miñano recolle no seu Diccionario, precedente claro do de Madoz, unha fermosa descrición xeolóxica da xurisdicción de Brollón, na que salienta: En lo demas de las sierras, de la cabeza del valle y lomas de éste, todas las canteras que se descubren son de piedra pizarra de varias especies, entre las cuales hay algunas de losa que sirven para cubrir las casas, pero son de mala calidad, á excepción de una de la que se extrae mucho en los términos de San Miguel de Vilademoro; en lo demas del valle no hay sino morrillos y guijarros de que resulta una piedra pedregosa y con mucha dificultad para construir edificios buenos. Sin embargo, hay muchas piedras de estas muy gruesas y de un excelente grano para afilar, con especialidad en el riguero de Picarrejo de la Ferreirua. (Miñano y Bezoya 1827: 170).
} 


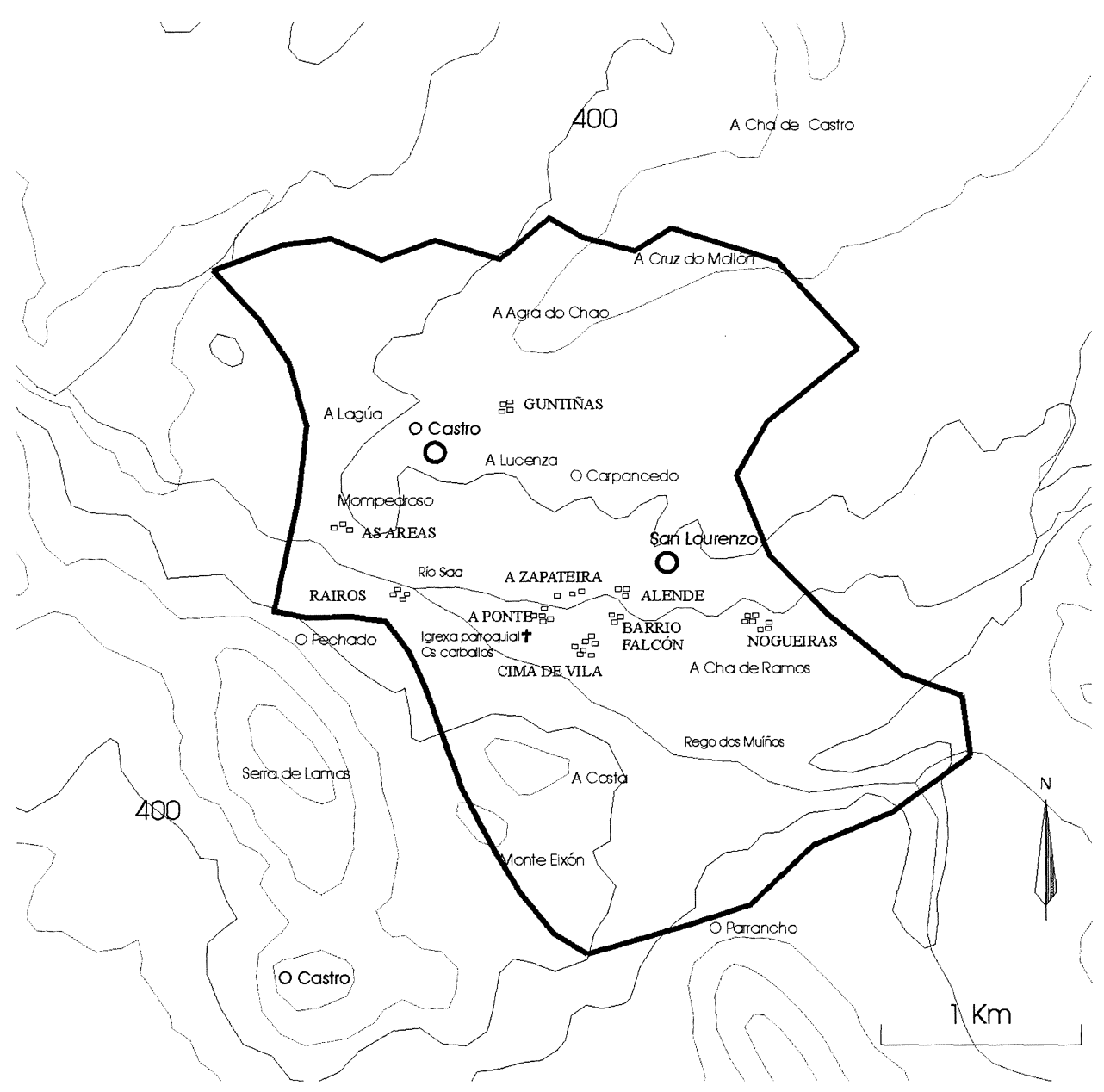

Figura 3.- A parroquia de S. Pedro de Cereixa.

\section{Unha paisaxe monumental: a necrópole megalítica}

Non posuímos datos sobre o primeiro poboamento humano na zona de estudo, pero si contamos con evidencias documentais de época histórica que amosan a existencia dunha necrópole tumular neolítica no límite natural suroriental da parroquia. Deste xeito, a escala macroespacial, dos momentos correspondentes ó Neolítico, as únicas evidencias arqueolóxicas detectables limítanse ós exemplos de arquitectura monumental ou túmulos funerarios (coñecidos na zona como modorras) que se espallan, na súa meirande parte formando grupos, polas terras altas das estribacións montañosas. 
O fenómeno tumular na zona centro-sur da actual provincia de Lugo non acada o grao de intensidade que se constata noutras áreas de Galicia. De feito, estas poboacións prehistóricas privilexiaron o emprazamento das necrópoles nas terras altitudinalmente medias, polo que se constata un baldeiro destes xacementos nas zonas baixas -ocupadas daquela por unha masa boscosa e pouco atractivas para a tecnoloxía agraria neolítica- (Depresión de Lemos, A Mariña e vales interiores) e en certas terras altas como Ancares e O Courel (Rodríguez Casal et al. 1997). Neste senso, as grandes necrópoles localizadas ubícanse nas estribacións das serras orientais de O Courel, nos actuais concellos de O Incio (necrópole de Santa Mariña), Samos (área tumular de Serra do Edramo-Alto das Nogueiras) e Quiroga (necrópole de Vilar de Lor). Complementan a estas, pequenos conxuntos emprazados en penichairas e pequenas dorsais, como pode se-lo caso que nos ocupa.

A este respecto, o Catastro de Ensenada ${ }^{3}$ preséntase coma unha fonte histórica de incalculable valor, xa que nos permite documenta-la existencia dunha necrópole, actualmente desaparecida, e que foi reutilizada simbolicamente para a definición dos límites parroquiais, como queda patente na descrición recolleita no Interrogatorio General (ano 1753):

[...] De este sube al marco que esta enel Alto dela Sierra de Cutarelos, y en el camino real que por ella pasa del expresado Coto de Zereixa para la Villa de Monforte; Desde el porel camino avajo al marco que nomina da Cruz do pechado, de aqui atraviesa y sigue al quellaman do loureiro dobale y se alla en el camino queva del mismo coto de Zereixa para la frâ de Chavaga; De el sube al que se denomina da modorra da poza, de este al damodorra das fontes que se alla a la parte $S$ confinando con las referidas fras de Chavaga y Pinel; De aqui âtrabiesaadar por junto a la cortiña nombrada de las pedrerías de Pinel que hes de Domingo de la Iglesia vezino de la mencionada frâ de Santa María de Pinel. Desde ella sube al alto de la sierra de vilarello y ado llaman pena darca. Deesta baxa a la modorra nominada da carballeiras de Vilarello, de ella prosigue bajando al marco da modorra dos rramos que esta junto al camino real $q$ va de Cereixa para la frâ de Santa María de quinta de lor.

Esta referencia documental permite unha localización exacta da situación destes túmulos megalíticos, que repostan a un modelo de emprazamento espacial ben

\footnotetext{
${ }^{3}$ AHPL, Catastro de Ensenada, parroquia de San Pedro de Cereija, Interrogatorio General, Resposta ó Capítulo $3^{\circ}$ (ano 1753).
} 
definido para o NW, e que se corresponde con estudos de áreas cercanas á nosa como é o caso de Samos (Filgueiras e Rodríguez 1994). Así, as medorras configuran un espacio funerario que resulta da aplicación dunha estratexia de apropiación e semantización do espacio ocupado por esas comunidades (dorsais e penichairas), aparecendo intimamente vencelladas ás vías de tránsito natural tanto ó longo das serras como nos pasos ou collados que serven para salvar eses accidentes orográficos (Criado Boado 1989; Villoch 2000). Estas vías de comunicación mantéñense en época histórica sendo sancionados eses percorridos pola rede viaria medieval e posterior (Bello Diéguez et al. 1982), de aí que no documento citado non sexa casual a referencia ás medorras como verdadeiros mollóns dos camiños reais que cruzan a parroquia.

Por outra banda, a ubicación destes túmulos nas zonas de paso natural explican en parte a súa destrucción, xa que sufriron a construcción da liña férrea a finais do s. XIX, a construcción da N-120 e do alcumado empalme da estrada que serve de desvío en dirección a Sarria e Lugo. Tamén explica en parte a súa desaparición a utilización das terras nas que se ubicaban como áreas de explotación extensiva, zonas de monte nas que se procedeu a unha repoboación forestal selectiva e a unha apertura de áreas de pasto para o gando.

Outro aspecto interesante a ter en conta, e que comentaremos polo miúdo máis adiante, é o valor territorial dos túmulos como marcos ou sinalizacións de término dentro do espacio rural tradicional (Martinón Torres 2001). A paisaxe prehistórica megalítica, carente xa da súa funcionalidade e, o que é máis salientable, do seu sentido orixinal, é reinterpretada de novo por outra comunidade campesiña, diferente á neolítica, pero cunha concepción moi clara do espacio que habita e explota. Prodúcese un novo proceso de semantización no que as ruínas arqueolóxicas dun espacio habitacional e cultual abandonado, se utilizan como eixos delimitadores e vertebradores dunha nova paisaxe cultural.

\section{O poboamento da Idade do Ferro: o descenso cara o val}

Carecemos de rexistro arqueolóxico que poida facilitar datos sobre o hábitat na Idade do Bronce para a zona obxecto de estudio polo que centraremo-la nosa atención na conformación, no $\mathrm{I}^{\mathrm{o}}$ Milenio a. $\mathrm{C}$., dun novo modelo de poboamento caracterizado pola aparición dos primeiros poboados fortificados. Para o ámbito galego, as analíticas espaciais aplicadas ós estudos sobre poboamento castrexo a escala comarcal e a investigación desenvolta dende a Arqueoloxía da Paisaxe (Penedo e Rodríguez 1991; Parcero 2000, 2001) facilita a nosa comprensión da concepción territorial e a nova forma de construcción da paisaxe social xerada pola sociedade castrexa. 
Neste senso, o castro, fito monumental construído para ver e ser visto, simboliza (mediante as fortificacións, o emprazamento, a visibilidade e maila visibilización), a territorialización das comunidades campesiñas e guerreiras da Idade do Ferro e o xurdimento dunha paisaxe domesticada. O patrón de emprazamento destes asentamentos supón un descenso cara as zonas baixas, os vales fluviais, ubicándose en outeiros ou a media ladeira no punto de transición entre as actuais terras adicadas a monte (cultivos extensivos, explotación de recursos forestais) e a labradío (agricultura intensiva, horticultura). Atópamonos perante o precedente máis claro do artellamento do que a posteriori será a paisaxe rural tradicional galega (Criado Boado 1989).

Neste proceso de territorialización e de domesticación da paisaxe identifícase a sucesión de dous modelos de ocupación (Idade do Ferro I e Idade do Ferro II) así como notables diferencias en función das áreas xeográficas, polo que a dinámica sociocultural das áreas de interior, como pode se-la Terra de Lemos, diferirían na práctica notablemente en comparanza con zonas máis dinámicas do $\mathrm{S}$ da actual Galicia e do litoral. A este respecto, cremos que para a nosa área de estudio, densamente poboada dende esa época, existe unha continuidade clara dende a Idade do Ferro I no tocante á elección do emprazamento dos poboados fortificados, debido fundamentalmente ó condicionamento xeográfico imposto pola depresión de Lemos que potenciou a fortificación dos outeiros máis senlleiros e conspicuos na paisaxe, cinguindo claramente as zonas de val (Ayán 1997).

Como se pode apreciar na figura 5, os castros da zona ubícanse por norma xeral en extremos de dorsais de estribación e en pequenos outeiros que preceden ós vales fluviais, preto tanto das terras con condicións agropecuarias destacables coma daquelas propicias para unha explotación extensiva. Estes poboados fortificados definen unha malla de intervisibilidades controlando os cursos dos ríos e as vías de comunicación naturais de acceso ó val de Lemos. A este patrón resposta $A$ Coroa ou o Castro, situado na nosa parroquia. $O$ Castro sería un dos poboados fortificados habitados polo pobo dos Lemavos, etnónimo recollido nas fontes clásicas ${ }^{4} \mathrm{e}$ que daría nome en época histórica á Terra de Lemos.

${ }^{4}$ Aparecen citados por Ptolomeo (II, 6, 25) ubicando a súa capital en Dactonium (Monforte de Lemos?) e Plinio (Nat. Hist., III, 28) segundo o cal o convento Lucense ten ademais dos Célticos e Lemavos 16 pobos de nome descoñecido e bárbaro, pero ten case 666.000 homes libres (Romero Masiá e Pose Mesura 1987: 65). Á súa vez, Justino (XLIV) subliña a riqueza en ferro da zona e o papel xogado polo actual río Cabe: entre eles non se proba unha arma que non se templara ou no rio Birbili ou no Chalibo. Polo que tamén se dí que os viciños deste rio se chaman Chalibes e que coas armas aventaxan ós demais. (Citas textuais tomadas de Romero Masiá e Pose Mesura 1987). 
Ubicado nun outeiro cun amplo dominio visual, controla tanto a bacía baixa do río Saa coma a penichaira da Cha de Castro, mantendo unhas claras relacións espaciais con outros xacementos probablemente coetáneos (Castroncelos, Castrosante, Chavaga). Posúe un recinto superior ( $A$ Coroa), de planta elíptica, que se continúa cara o $\mathrm{W}$ cun aterrazamento anexo. Atópase cuberto dunha mesta vexetación e non presenta un bo estado de conservación debido ás alteracións sufridas co gallo da actividade extractiva de area levada a cabo nos anos 70 .

Trátase dun bo exemplo dun modelo de poboamento, o castrexo, que, tras perdurar practicamente un milenio, experimentaría notablemente o impacto dun factor esóxeno: a chegada de Roma ó NW peninsular.

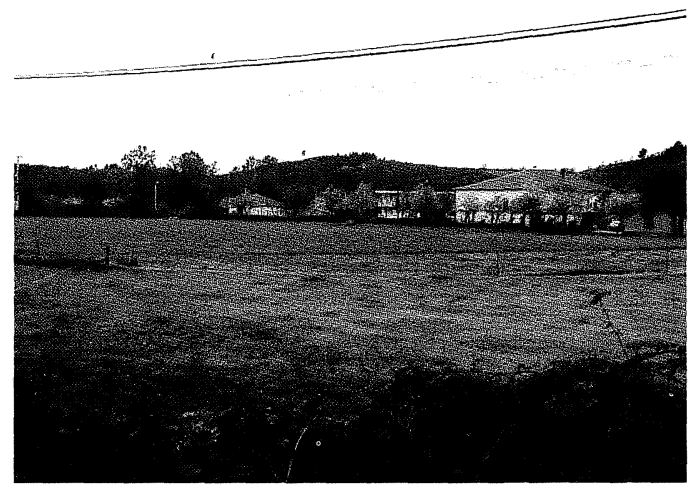

Figura 4.- A Coroa/O Castro: referente visual na paisaxe da bacía baixa do río Saa.

\section{A implantación romana dunha paisaxe mineira}

Dentro do NW peninsular a zona conformada polos actuais concellos de Quiroga, Ribas de Sil, Pobra de Brollón, O Courel e Samos foi unha das principais áreas de captación de recursos auríferos por parte do Imperio romano trala conquista do territorio. A riqueza aurífera da bisbarra deu lugar a un sistema de explotación intensivo entre os séculos I-II d. C. modificando radicalmente a paisaxe e a evolución histórica das comunidades indíxenas que alí vivían. A este respecto, a citada área é o territorio de Galicia que mellor exemplifica todo ese proceso de cambio socioeconómico, xa que se conservan na actualidade centos de explotacións auríferas, os poboados fortificados construídos por Roma para albergar ós traballadores e, á súa vez, controla-lo territorio, as minas abertas e as novas vías de comunicación. 
Nas dúas últimas décadas desenvolveuse una liña de investigación sobre as explotacións auríferas nas bacías dos ríos Sil, Lor e Cabe, baseada nun estudio arqueolóxico sistemático da zona, que permite caracterizar tódolos elementos arqueolóxicos vencellados a ese proceso: castros mineiros, minas e vías de comunicación (Luzón et al. 1980; López González 1993). Esta zona presenta unha grande complexidade de labores mineiros e un relativo bo estado de conservación, polo que a infraestructura hidráulica fornece documentación de abondo para reconstruir todo o proceso tecnolóxico da minería, e maila súa influencia na distribución do territorio. Asemade, atopámonos perante unha paisaxe mineira en parte fosilizada, que ten sufrido escasas modificacións dende o abandono das explotacións mineiras romanas (López González 1993, Ayán 1997).

Neste contexto, o modelo de ocupación romano basése nunca doble dinámica: por unha banda, aproveitamento selectivo dos poboados fortificados anteriores, dependendo de características estratéxicás, económicas e da relación con outros asentamentos, e, por outra, a creación de novos recintos castrexos como forma de impoñer unha nova articulación demográfica e territorial, vencellados á explotación económica agrícola e mineira.

No Val de Quiroga, Pobra de Brollón e O Courel abundan este tipo de asentamentos, cunha morfoloxía que se ben se cingue á tradición castrexa, son fundacións ex novo relacionadas cas explotacións auríferas, o control do transporte do ouro extraído e a política colonizadora levada a cabo por Roma. Son un producto e á súa vez un axente máis dunha actuación imperialista sobre o territorio, caracterizada pola intensificación agropecuaria, a introducción dunha minería industrial, e a creación dunha serie de servicios entre os que destaca a creación dunha rede viaria. Estes castros mineiros presentan unha morfoloxía complexa e se constrúen moitas veces aproveitando técnicas mineiras para ergueren o sistema defensivo.

A instauración deste novo modelo de poboamento vése claramente na nosa zona de estudo ó realizarmos unha análise espacial a escala comarcal dos xacementos castrexos. Deste xeito, constrúense no s. I d. C. unha serie de asentamentos ex novo ubicados nas cercanías das propias explotacións, preto dos cursos fluviais e xerando unha rede de intervisibilidades que abrangue todo o territorio.

O Castro da Lende ou San Lourenzo é un dos xacementos paradigmáticos deste tipo. Descoñecemos se se abandoa o antigo poboado fortificado da Idade do Ferro de $A$ CoroalO Castro ou se continúa ocupado cando se levanta este novo asentamento fortemente arquitecturizado, nun emprazamento privilexiado que permite controla-la espectacular explotación aurífera de $O s$ Medos, así como a vía de comunicación natural en dirección E-W polo val do río Saa e maila vía que, proce- 


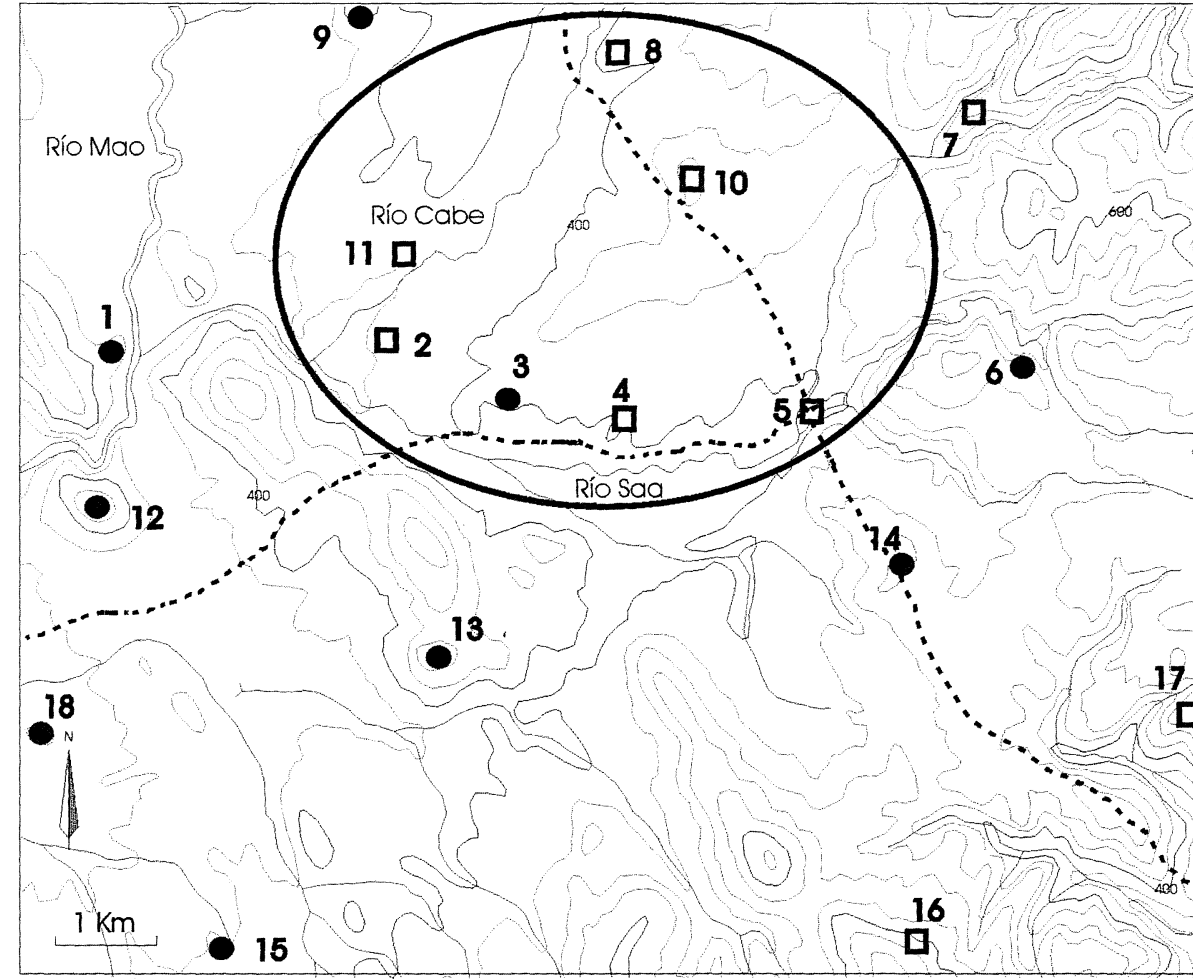

Castros prerromanos

$\square$ Castros mineiros de época romana

$\bigcirc$ Área de explotación aurífera secundaria (Os Medos e outras)

.... Vías de comunicación antigas

1. Castro da Parte; 2. Montecelo; 3. O Castro/A Coroa; 4. Castro da Lende/San Lourenzo;

5. Castro da Pobra; 6. A Roda (Lamaigrexa); 7. A Roda (Saa); 8. Castro Leboreiro; 9. Castro de Piño; 10; Castrosante; 11. A Modorra; 12 Cornado; 13. Castro de Chavaga; 14. Castroncelos; 15. Castro de Caneda; 16. A Cerca dos Mouros; 17. A Roda do Castro; 18. O Castelo Grande.

Figura 5.- Pobomento da Idade do Ferro e a implantación dunha paisaxe mineira (s. I d. C.) na zona de estudio.

dente do S, do río Lor, se interna no val de Lemos en dirección ós codos de Belesar no río Miño.

O castro da Lende, situado a uns $200 \mathrm{~m}$ ó NE da aldea da Lende, no coto coñecido como San Lourenzo, está bordeado polo W polo regato homónimo que serve de foxo natural. O poboado posúe un recinto elíptico delimitado en todo o seu perímetro por unha muralla de pedra construída con coios de cuarcita e lousas. 
O sistema defensivo refórzase por unha dobre liña de parapetos e fosos no arco NE-SW, o de meirande accesibilidade dende as terras chas da Agra de Castro. A zona meridional do xacemento atópase moi deteriorada por mor da canteira aberta nos anos 70 que conlevou a construcción dunha pista que corta as estructuras ata o interior da croa.

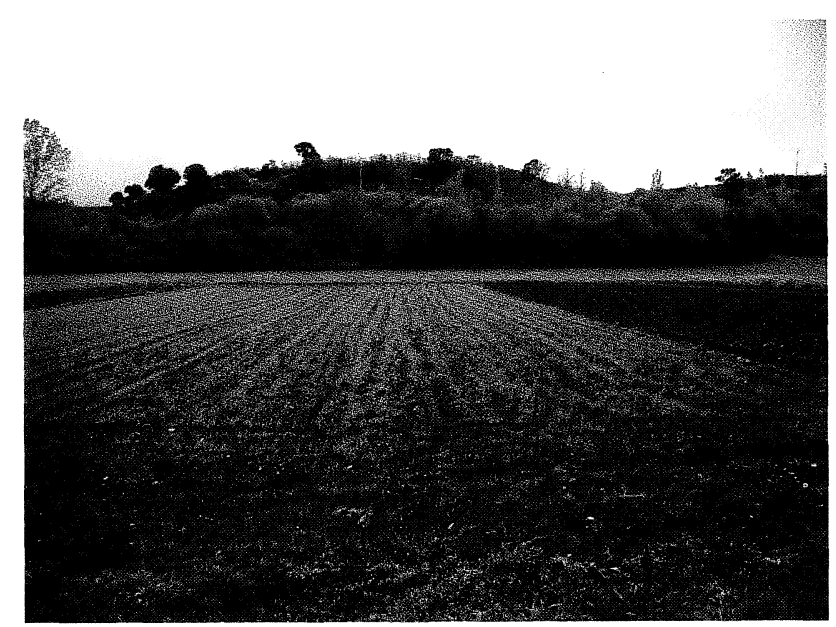

Figura 6.- Vista xeral cara o $\mathrm{N}$ do castro mineiro romano da Lende/San Lourenzo.

A enquisa etnográfica aportounos datos sobre a existencia dunha mina de ferro, da que se conserva unha galería coñecida coma o Burato dos Mouros, así como da utilización do castro como zona de extracción de pedra para a construcción das casas do lugar de Alende. Asemade, algúns dos antigos traballadores na canteira aseguráronos que se atopara un camiño de acceso ó castro, con marcas de rodeiras, así como utensilios de ferro. Outro dato fundamental para acadar unha valoración arqueolóxica da funcionalidade do xacemento é a presencia de pequenas explotacións auríferas no entorno inmediato do castro (reflectidas no microtopónimo mineiro As Grovias) e a existencia dunha parcela próxima ó lugar de Nogueiras, ó carón do río Saa, coñecida coma $O$ Escourial $^{5}$. Neste lugar vénse ciscadas aínda

${ }^{5}$ A antigüidade deste microtopónimo e da existencia do propio escourial evidénciase no Catastro de Ensenada o referirse ós límites da parroquia da Pobra: [...] baxando al rrío Zereixa yatravesandolo porel sitio quella man hescourial ba al marco de Rañoa que se alla en el Camino Real. AHPL, Catastro de Ensenada, Villa de S. Pedro de la Puebla del Brollón, Interrogatorio General, Resposta ó Capítulo $3^{\circ}$ (ano 1753). 
numerosas escouras de ferro que delatan a utilización dunha tecnoloxía de procesado de mineral mediante a utilización de fornos reductores con sangrado de escoura, introducidos por Roma no NW. O tamaño inxente deste escourial dedúcese da recollida sistemática de escouras na década de 1960 por unha empresa siderúrxica asturiana, así como a súa utilización para pavimenta-las pistas da parroquia deica $o$ seu asfaltado definitivo a comezos da década de 1990.

Esta confuencia de datos permítenos tracexa-la hipótese de que o Castro da Lende puido ser un poboado metalúrxico especializado na extracción e producción de ferro, enmarcado dentro do sistema de explotación sistemática do territorio desenvolto polo poder romano, á semellanza do que acontece na Zona Arqueolóxica das Médulas, na que o reordeamento do territorio e a configuración dunha paisaxe mineira conlevou a aparición, non só de explotacións a grande escala, senón tamén o xurdimento de poboados metalúrxicos especializados coma o castro de Orellán (Sánchez-Palencia et al. 1996).

O xacemento integrouse, polo tanto, nun novo modelo de implantación territorial, esencialmente fundamentado en intereses económicos, e producto dunha conxuntura política concreta. Falamos de conxuntura porque, segundo a investigación actual, sitúase o abandono total deste sistema de explotacións mineiras, e dos poboados habitacionais asociados, a inicios do s. III d. C. A este respecto compartimos plenamente a idea apuntada por T. Rodríguez Fernández (1994: 172) para a zona veciña de Sarria-Samos: Este modelo "estatal» (altoimperial) de ocupación territorial se establece superponiéndose a lo indigena $y$, una vez finalizada la coyuntura que le dio origen, parece desaparecer sin apenas dejar más huella que los propios yacimientos arqueológicos, es decir, parece ser un modelo sin continuidad temporal, un modelo fosilizado en el paisaje. Es un acontecimiento que no trascendió a los individuos que lo protagonizaron, y por tanto no puede ser calificado de aculturación.

Deste xeito, a bacía do río Saa formaba parte dunha área marxinal e periférica que só acadou unha certa importancia como espacio de explotación en época altoimperial, así como pola súa ubicación preto da vía de comunicación aberta para acceder á terra de Lemos dende a bacía do río Sil. A pervivencia do sustrato, do modelo de explotación agrícola e do patrón cultural indíxenas pode explica-la marcada continuidade do tipo do hábitat ${ }^{6}$, xa que, se ben se abandoan algúns castros

${ }^{6}$ En Samos-Sarria o $71 \%$ dos castros mantivéronse ocupados como emprazamento habitacional ata a actualidade (ubicación da aldea tradicional no propio castro extramurallas ou na mesma situación fisiográfica) fronte ó $28 \%$ dos xacementos abandonados; pero, aínda así, algúns destes foron sancionados simbólicamente coa construcción de capelas (Rodríguez Fernández 1994: 181). 
en época tardía, a meirande parte deles (ningún deles castro mineiro romano) acollerán no seu seo ou no seu entorno inmediato a aldeas altomedievais.

\section{Cadro I}

Cristianización e perduración do hábitat nos castros da zona de estudio (Figura 5).

\begin{tabular}{cccccc}
\hline Castro & Capela na coroa & Igrexa na coroa & Igrexa ó pé & $\begin{array}{c}\text { Aldea sobre } \\
\text { o castro }\end{array}$ & Aldea ó pé \\
\hline $\mathbf{1}$ & & Santa María & & A Parte \\
$\mathbf{3}$ & & & & Guntiñas \\
$\mathbf{4}$ & San Lourenzo & & A Pobra & \\
$\mathbf{5}$ & & San Pedro & & Burgum Pinu & \\
$\mathbf{9}$ & & Santa María & & Castrosante & \\
$\mathbf{1 0}$ & & Santa Mariña & & O Alto/Pacios \\
$\mathbf{1 3}$ & & & San Xoán & & \\
$\mathbf{1 4}$ & & Santiago & Castroncelos & \\
$\mathbf{1 5}$ & & Santa Baia & & Eirexa \\
\hline
\end{tabular}

\section{A organización do territorio en época altomedieval: do castro á villa}

Tralo abandono definitivo das explotacións auríferas por Roma no século III d. C. agromou na bisbarra unha nova realidade sociocultural, como foi a aparición dun novo modelo de poboamento baseado na aparición de aldeas abertas sen connotacións defensivas. Porén, este proceso de formación dunha nova paisaxe sociocultural, sancionada pola cobertura ideolóxica cristiá, presenta na nosa zona de estudio unha doble vertente: por unha banda, produciuse unha ocupación intensiva das zonas de fondo de val e, por outra, mantívose en grande medida o poboamento nos antigos castros.

$\mathrm{O}$ xérmolo deste proceso ambivalente atópase no artellamento territorial e político do Reino Suevo nos séculos V e VI, período no que algúns castros senlleiros continuaban habitados e no que se desenvolve o hábitat disperso de aldeas abertas que amosaban na súa toponimia a presencia de possesores xermánicos. Para o caso que nos ocupa contamos, por unha banda, coa constatación documental de que o veciño castro de Zavaga (Chavaga) formaba parte do territorio do condado paramiense (David 1947) e, por outra, coa evidencia da existencia dentro da parroquia da aldea de Guntiñas, a única de clara toponimia xermánica, e ubicada en alto, nunha chá ó pé de $O$ Castro/A Coroa, existindo polo tanto unha continuidade do poboamento entre o castro fortificado e a nova aldea aberta. 
Este proceso de artellamento territorial acadaría a súa plenitude entre os séculos VIII e X, momento no que se consolida a ocupación do fondo de val da bacía do río Saa, seguindo unha dinámica común a toda a Galicia da época. Neste senso, a escala macroespacial, neste período aparece claramente definida unha organización comarcal do territorio que, recollendo, ás veces, nomes xentilicios, toma como referentes de demarcación fundamentalmente os ríos, os montes e os vestixios do poboamento castrexo, perceptibles aínda pola sociedade campesiña altomedieval.

Para a nosa zona de estudo contamos coa demarcación do coto do mosteiro benedictino de S. Vicenzo do Pino, gracias á preservación dun documento datado no ano 847, que nos dá unha idea senlleira do artellamento no s. IX da antiga terra de Lemos. O límite partía dos montes de Pena Ventureira e Nibueiro (ó NW de Monforte) e dirixíase cara o E cruzando os ríos Noceda e Mao para achegarse por Ribas Pequenas e seguir o curso do río Cabe (Ferreira Priegue 1988: 225):

et feret in rivolum Chave ad illa villa que dicent Purcis, et vadit quomodo venit Chave usque ad Fornellas, et vadit per illum rivolum que dicent Cerosia usque feret et item per illum portum de Ferraria et vadit in directum per illa aqua de Cerosia usque in portum qui vocitam Portoesia, et feret in illa semita antiqua que venit de Castrosancto et concludet inde per illa semita antiqua que vadit sub illa villa de Pignario totum per illa semita antiqua usque circa Lupos, et item pergit de alia parte Lor usque ad cacumen montium que vocitant Vilar Planu et concludet per verticem montem, et pervenit ad illas traavesas inter Lor et Caricoca, per castro de Arias, et desecendit ad flumen Syle.

Eis como o poboamento se artella nas villae implantadas nos vales fluviais dos ríos Chave (Cabe) e Cerosia (o actual río Saa que deu nome a parroquia de Santa María de Saa, aínda que o río curiosamente sería coñecido en época histórica coma o río de Cereixa) e como se definen xa os territorios de Lemos, Lor e Quiroga, ós que tamén se refire un documento do mosteiro de Celanova datado no ano 886 (Baliñas 1992: 348):

Donamus vobis villas que dicunt Salzeto, Villaplana, Dominici, et sunt ipsas villas territorio Lemaos secus rivulo Laure?

${ }^{7}$ Estes topónimos refírense a vilas que foron a orixe das actuais parroquias de S. Xoán de Salcedo, San Mamede de Vilachá e a aldea de Domiz (pertencente a Salcedo), núcleos todos eles integrados no actual concello da Pobra de Brollón.

Cuadernos de Estudios Gallegos, Tomo LII, Fascículo 118, Santiago 2005. (Págs. 117 - 172) 
A escala microespacial, a vila, segundo a investigación medievalista galega (Baliñas 1992: 194-230; Andrade 1996; Portela e Pallares 1998) pode considerarse coma unha aldea cun territorio sempre moi ben delimitado (por un río e polas vilas veciñas) e un conxunto de actividades humanas relacionadas coa habitación e explotación da terra nos séculos IX e X. Preséntase coma a célula básica de ocupación do territorio, coma unha estructura ben asentada que, sobre a base da distinción entre núcleos habitados, terrazgos e espacios incultos, caracterizarase por unha flexibilidade notable que permite a súa adaptación a condicións sociais cambiantes.

Estas vilas, co seu territorio acotado por marcos ou referencias físicas, así como ruínas arqueolóxicas como monumentos megalíticos ou miliaros romanos (Andrade 1996: 279-80) acabarán convertidas nas actuais parroquias galegas. Este semella se-lo caso da nosa parroquia de Cereixa, resultado dun primitivo núcleo de poboación tipo vila do que queda constancia no nome da aldea de Cima de Vila e emprazada efectivamente nunha cota máis alta que a zona na que se ubicaría a primitiva igrexa altomedieval. O territorio desta vila, ceñido polo das veciñas vilas de Fornellas, Castro Sancto e Braulione, semella corresponderse punto con punto cos límites que aparecen reflectidos no Catastro de Ensenada.

Así pois, estamos ante a formación dun proceso de organización do espacio de moi longa duración que dará lugar a unha continuidade histórica ata a actualidade na configuración dun hábitat estable, por parte dun campesiñado fixado a un territorio concreto que permanece inamovible ata hoxendía. Como sinalan os profesores Portela e Pallares para o entorno inmediato de Celanova (1998: 42-3): No podemos conocer con total exactitud la cronología y los pasos sucesivos del proceso que condujo del sistema de los castros al sistema de villae. Cuando, a partir del siglo VIII, las fuentes escritas nos ponen el segundo ante los ojos, su realidad, bien asentada ya, es el resultado de una evolución larga que, desde el punto de vista de las relaciones sociales, se manifiesta en una jerarquización sólidamente establecida. En el tránsito del siglo XX al XXI, es posible reconocer todavía, aunque tal vez ya no por mucho tiempo, los rasgos básicos -la delimitación general, la disposición de los núcleos habitados, la distribución de los campos de cultivo- de la estructura que hemos estudidado en el tránsito del siglo X al siglo XI.

As comunidades campesiñas asentadas na bacía do río Saa configuran un hábitat disperso en aldeas dando lugar a un sistema de artellamento do territorio que acabará sendo subsumido polo proceso de protofeudalización incentivado pola presión exercida polos poderes monásticos. Deste xeito, a rica e fértil Terra de Lemos sería un territorio no que os grandes mosteiros promocionados pola monarquía astur, como Samos e Celanova, comezaron a definir o patrón de poboamento e a abranguer paseniñamente amplos territorios nos que a poboación campesiña se vía 
privada do uso libre sobre a propiedade da terra, proceso consolidado no século XI, como podemos ler en senllas doazóns feitas ó mosteiro de Samos da varias vilas na terra de Lemos:

Et III ${ }^{a}$ villa in Lemabus, que fuit de Luliano et ipsa villa vocabulo Ceresia, (Santa María de Saa) et habuimus ipsa villa per suum pretium subtus basilica sancte Marie, discurrente rivulo Cerasia, et est per termino de Laurenti, et inde per termino de sancto Petro, et inde per Braulione, et inde per Castro Sancti, et inde per Ferrarios. (Documento do ano 1050 recollido en Lucas Álvarez 1980: 286-7).

Et est ipsa villa Ferrerua iuxta aula sancti Martini per terminos de monte Aguto et inde per aqua de Cerasia et inde per Castro Sancti et inde per Sancta Eulalia de Rege et inde aqua in festo de Cabi ubi dicent Palatio. (Documento do ano 1074 recollido en Lucas Álvarez 1980: 468).

Atopamos plenamente conformado o mundo rural plenomedieval, definido polo protagonismo do poder señorial monástico e o enmarcamento do campesiñado nunca estructura espacial que vai en camiño de conformarse como parroquial (Andrade 1996: 290).

\section{A parroquia plenomedieval na xurisdicición da Pobra de Brollón}

$\mathrm{Na}$ documentación referida á zona dos séculos XII e XIII vése claramente como se define plenamente o sistema de organización parroquial; das referencias ó Cerosia Rivolum como eixo articular do espacio pásase á cita expresa de núcleos de poboación cunha igrexa parroquial; velaí as referencias a San Pedro de Cereija (documentos da catedral de Lugo do 1 de abril de 1235), Eijion Ecclesia (San Xurxo de Eixón), Ecclesia Pinu Sancta María (Santa María de Piño) ou Abrenze in Lemos (San Xoán da Brence) (Rielo Carballo 1975).

Xogaría un papel fundamental na configuración da parroquia a importante vía de comunicación que viña dende o val do Sil e ía á Pobra de Brollón, dende onde, seguindo o curso do Saa, pasaba por Cereixa, onde cruzaba a serra, e dende e alí a Monforte de Lemos pola aldea de Rosela. Esta ruta de acceso natural a Galicia, de orixe romana, continuaría sendo unha vía de tránsito fundamental en época medieval como así o amosa o feito de que permanecería o mesmo modelo viario á hora de enfrontarse cos condicionamentos orográficos (Nárdiz 1992: 152-3).

Por outra banda, semella claro que esta ruta cara o interior de Galicia acadaría unha grande importancia como ruta comercial e favoreceu a aparición de dous burgos ubicados nas abas de dous castros:

Cuadernos de Estudios Gallegos, Tomo LII, Fascículo 118, Santiago 2005. (Págs. 117 - 172) 
- A vila de Pobra de Brollón, no camiño cara o N, probablemente relacionado coas primeiras peregrinacións a Santiago.

- A vila de Monforte de Lemos, no centro da depresión de Lemos, e principal núcleo de poboación na ruta occidental.

O xurdimento da Pobra de Brollón constituirá o eixo vertebrador dun territorio xurisdiccional no que se integraría a nosa parroquia. A este respecto, a investigación medievalista galega ten estudiado polo miúdo o fenómeno das cartas pueblas e maila promoción real de novas vilas nos séculos plenomedievais, sen que o caso da Pobra de Brollón apareza citado en ningún caso. Esta carencia quizais veña dada pola ausencia de documentación que nos permita analisa-la orixe deste núcleo de poboación. A única referencia historiográfica que se atopa é a apuntada por Pascual Madoz (1847) quen afirma que la villa envió primeras juntas o cortes celebradas en León procurador o diputado, como uno de los pocos pueblos libres $y$ de realengo de Galicia, y que había recibido fueros particulares de Sancho IV el Bravo y Fernando IV el Emplazado.

Estes datos repítense deica a actualidade en calquera reseña sobre o concello pero se descoñece o seu grao real de veracidade. Non obstante, é certo que a Pobra de Brollón era unha xurisdicción de realengo, dependente directamente do monarca e polo tanto exenta das cargas feudais impostas polos señores nobres e/ou eclesiásticos. De feito, consérvase documentación sobre as queixas que o Concello presenta ós Reis Católicos en 1494 sobre as serventías e abusos extraxurisdiccionais impostos polo Conde de Lemos ós habitantes do alfoz de A Pobra (García Oro 1987).

A pesares da ausencia de documentación máis antiga, a nosa hipótese defende a posibilidade de que esta vila xurdise incentivada polo tráfico comercial relacionado co camiño xacobeo. Neste senso, A Pobra de Brollón sería un exemplo máis da articulación do poboamento interior de Galicia a base de pueblas reales promocionadas pola monarquía castelá-leonesa. Segundo García Oro: El regno de Galicia es poblado a fuero de León y Benavente, decían los procuradores gallegos en las Cortes de Valladolid en 1351. Los monarcas de la Galicia urbana no miraron sólo a su dentellado litoral. El Camino de Santiago y otros caminos menores reclamaron su imaginación. Surgirían pueblas viarias, como ya estaban naciendo villas portuarias y fronterizas. Nació Melide, Triacastela, Sarria. La etapa creadora de pueblas en Galicia rematará con el siglo XIII.

Como demostra E. Ferreira Priegue (1988), os burgos e pueblas non crearon novas redes de tránsito senón que consolidaron as xa existentes, xurdindo a rentes das vías romano-medievais. Semella claro que na Idade Media Galicia posuía unha rede de camiños artellada por tres rutas de penetración dende o E (o Camiño Fran- 
cés, a vía XVIII polo val do Sil e mailo acceso polo val de Monterrei) que coas súas ramificacións e complementos definen a comunicabilidade do interior galego.

A natureza viaria ${ }^{8}$ de A Pobra parece fóra de toda dúbida; ubicada nas abas dun castro central no val do Saa, serve de nó na Idade Media, xa que alí se bifurca un camiño real a Monforte de Lemos en dirección W. Asemade, a súa estructura urbana artéllase arredor do camiño xacobeo que cruza o río Rubín pola ponte romana: el camino que parte del puente de piedra, que es calle principal de esta villa segundo documentos do s. XVIII (Gil Merino 1952: 78).

No tocante á orixe deste núcleo de poboación documéntanse dentro das posesións do mosteiro de Samos os lugares de Braulione (Brollón) e Sancto Petro (actual Pobra) nunha doazón do ano 1050 (Lucas Álvarez 1980: 286-7). O alfoz da Povra aparece citado xa en 1309 nun documento do convento de Ferreira de Pantón ${ }^{9}$ (Fernández de Viana 1994: 49). Polo tanto, a fundación de Pobra tería lugar entre 1050 e 1309, é dicir, nos séculos XII-XIII, o período no que se crean tódalas pueblas galegas. No século XV coñécese xa como Ploba de Brolôô ou Proba de Brolón, como así aparece noutro documento do mosteiro de Ferreira datado no ano 1422 (Fernández de Viana 1994: 177).

Aínda que integrada na demarcación territorial desta xurisdicción da Pobra de Brollón, o couto e parroquia de San Pedro de Cereixa pasaría a depender directamente do Bispado de Lugo, nun intre que podemos situar no último tercio do século XIV. Este señorío de Abadengo xurde no contexto das loitas mantidas entre a burguesía da capital lucense e o Señor Bispo, conflicto no que destacou unha muller de fonda pegada na tradición popular, nada na parroquia de S. Pedro de Cereixa: María Castaña. Citando a Amor Meilán (1980: 659): Heroína según unos, como Vesteiro Torres y Aureliano J. Pereira, mujer vulgarísima y despreciable según el señor López Peláez, fue la famosa María Castaña o Mari-Castaña, de San Pedro de Cereija, casada con Martin Cego (...) Esta María Castaña estuvo con su marido y dos hermanos de éste al frente del partido popular de Lugo, que resistía al pago de los tributos que el obispo, como señor, imponía.

\footnotetext{
${ }^{8}$ A decadencia da vila virá dada pola creación dos modernos accesos e a chegada do ferrocarril que incentivou o crecemento de Monforte de Lemos e maila creación da Estación da Pobra de Brollón, que deixou á Pobra nunha situación periférica en relación ó acceso posteriormente sancionado pola estrada $\mathrm{N}-120$. Este feito demostra a importancia desta ruta antiga no nacemento e desenvolvemento histórico da vila medieval de Pobra.

${ }^{9}$ Et se mays val ca esto que nos vos diades de renda dámosvollo nos quanto sen os novos, su tal condiçon que seiades os nossos procuradores nos preytos, negoçios muvudos e por mover que nos avemos ou asperamos d-aver no alfoz da Povra (Fernández de Viana 1994: 49).
} 
Efectivamente, a liñaxe dos Cego, oriunda da Pobra de Brollón e de grande influencia na cidade de Lugo, lideraran unha revolta en 1386 contra o bispo lugués chegando a asasinar ó seu mordomo Francisco Fernández. O conflicto remataría coa solicitude de absolución por parte de María Castaña e o seu marido, Martín Cego, quen tentaron compensa-los danos causados á Sé lucense coa doazón do couto de Cereixa e un tributo anual de mil maravedís (García Oro 1977: 66).

Dende esta data, e ata comezos do XIX, Cereixa constituiría unha sobranceira excepción en relación co resto de parroquias da xurisdicción de A Pobra de Brollón e mesmo das da Terra de Lemos, xa que era a única freguesía sometida ó señorío de Abadengo representado polo bispo de Lugo, o cal tiña un centenar de parroquias, mais case todas concentradas na xurisdicción da capital ${ }^{10}$. Así aparece referenciada a parroquia no Interrogatorio General do Catastro de Ensenada:

El Cotto y Felegresia de San Pedro de Zereixa hes y perteneze a la Dignidad Episcopal de la Ciudad de Lugo y en su nombre al Ilustrísimo Señor Obispo de ella a quien se paga por rrazón de Letuosa, el mexor buey y alaxa de quatro pies que quede al fallecimiento de cada uno de los vezinos, sinque por razón de señorio y basallaxe sele concurra otra cosa alguna" ${ }^{11}$.

\section{A parroquia no Antigo Réxime}

Os datos fornecidos pola citada fonte histórica do Catastro de Ensenada, se ben nos remiten a un intre concreto, conxuntural (ano de 1753), permítenos ollar de primeira man a estructura socieconómica presente na parroquia durante o Antigo Rexime. Deste xeito, o Interrogatorio General amósanos unha economía rural cerealística de subsistencia baseada no monocultivo extensivo do centeo en rexime de ano e vez (polo que as terras descansaban 14 meses, os que van dende o momento da seitura ata o outono do ano seguinte); este cereal, o máis apto polas condicións agroclimáticas da rexión, tiña unha importancia fundamental na dedicación agrícola e na base alimenticia panificadora dos labregos da parroquia de Cereixa; cultivábase nas terras de segunda e terceira calidade, mentres que as de primeira calidade produzen sin yntermision en un año trigo y al siguiente mais alternativamente ${ }^{12}$.

\footnotetext{
${ }^{10}$ Cómpre sinalar que a meirande parte da provincia de Lugo estaba dominada polo señorío secular que abranguía o $73.5 \%$ das freguesías da provincia; seguido do señorío Eclesiástico cun $19.2 \%$ e o Abadengo con outro $10 \%$.

${ }^{11}$ AHPL, Catastro de Ensenada, Coto y Feligresía de San Pedro de Cereija, Interrogatorio general. Resposta ó $1^{\circ}$ Capítulo (Ano 1753).

${ }^{12}$ Resposta ó Capítulo $4^{\circ}$.
} 
Os rendementos eran moi baixos en relación con outras zonas de Galicia: para o trigo de 5 ferrados por medida de terra cultivada, para o millo de $4 / 1$ e para o centeo nos terreos de segunda calidade $5 / 1$ e nos de terceira $3 / 1$. Esta agricultura de labrantío de base cerealística víase complementada coa explotación intensiva das cortiñas centrada no cultivo de hortalizas e legumes, a apicultura (125 colmeas), o cultivo dalgunhas viñas e parrais, e o aproveitamento dos abundantes soutos, acadando a castaña un posto sobranceiro na dieta alimenticia dos labregos. A cabana gandeira (cun predominio do gando vacún), pola súa banda, tiña unha grande importancia na economía e no ciclo productivo, constatándose a presencia maioritaria dos contratos de aparcería no tocante á propiedade do gando.

Dos 2590 ferrados de sementeira de centeo, 800 eran de terra de secano, 12 de terra de hortaliza, 50 de viñas, 12 de parrais, 16 de prados de secano, 160 de soutos, 200 de montes baixos pechados e de particulares, 40 de devesas e 1300 de montes comúns abertos (catro ferrados destes serven de pasto como prados de secano). Este último dato reflicte a importancia do monte do común, do aproveitamento da propiedade colectiva, na subsistencia da comunidade, pois tanto servían de pasto para o gando, como para o cultivo do centeo ou para a producción de toxo para o estrume. A este respecto, os montes comunais de primeira calidade rompíanse cada trinta anos (cun rendemento 4/1), os de segunda cada corenta (cun rendemento de $3 / 1$ ) e os de terceira cada cincuenta anos (cun rendemento de 2/1).

Pola súa banda, o Libro Personal de Legos permítenos deduci-lo tamaño, tipoloxía e estructura dos agregados domésticos que constituían a parroquia de San Pedro de Cereixa en 1753. Esta presenta unha media de 5,07 persoas/fogar coincidindo, polo tanto, cunha característica sobranceira do territorio da vella provincia luguesa que o diferencia do resto de Galicia: o grande tamaño das familias campesiñas. Deste xeito, na diócese de Lugo as medias por riba de cinco persoas/ fogar deixan de se-la excepción para convertérense en regla; nas montañas orientais dende Burón deica O Courel cénsanse de 5,5 a 7 persoas por lume; en Castroverde, Lugo e Chantada entre 5 e 6 , e unhas cinco nos núcleos de poboación do concello de Monforte; media, ésta última na que se insire o índice de conversión hab./fogar de San Pedro de Cereixa.

A este respecto, a análise do censo de 1860 realizada por P. Saavedra (1994: 1824), amosa como este elevado promedio se mantén a mediados do século XIX; o concello de A Pobra de Brollón presenta unha media de 5,26, Monforte 4,68, O Courel 6,43 e Bóveda 5,35. O resto de concellos da Terra de Lemos tiñan unha media moi inferior a 5. Neste contexto, a nosa parroquia, segundo a referencia fornecida por P. Madoz tiña, na década de 1840, uns 63 vecinos y 321 almas do que se deduce un índice de conversión hab./fogar de 5,09, é dicir, unha cifra

Cuadernos de Estudios Gallegos, Tomo LII, Fascículo 118, Santiago 2005. (Págs. 117 - 172) 
practicamente idéntica á de 1753 , e que nos indica que a realidade evidenciada polo Catastro de Ensenada non tiña nada de conxuntural.

Asemade, cómpre indicar que Cereixa, dende o punto de vista xeográfico e socioeconómico, se atopa nesa zona de transición entre a montaña de O Courel e as zonas meridionais da Terra de Lemos, de aí que a súa media de hab./fogar poida ser considerada coma ponte entre o elevado tamaño das comunidades das serras orientais, cunha economía baseada no cultivo do centeo en rexime de ano e vez, e o menor tamaño dos agregados domésticos de territorios (Pantón, Sober, sur de Monforte, Ribas de Sil) próximos á ribeira do Sil, caracterizados pola importancia da base vitivinícola nas súas economías. Este elevado tamaño dos agregados domésticos da parroquia, cun predominio das familias de 4 e 5 membros, así como a elevada media de 1,8 fillos vivos/ matrimonio explícase considerando os condicionamentos impostos polo sistema agrario imperante na comarca.

Deste xeito, os baixos rendementos da producción, as restriccións comunitarias á ampliación do espacio cultivado, e as propias esixencias laborais dunha agricultura-gandeiría extensiva baseada no cultivo de centeo en rexime de ano e vez, e cun amplo aproveitamento do monte a través do sistema de rozas, condicionan unha forza de traballo moi numerosa, e polo tanto, a constitución de grupos domésticos-unidades de explotación máis amplos. Por outra banda, o predominio da millora como práctica hereditaria non favorecía tampouco a creación de novos agregados domésticos; asemade o forte sentimento da casa pode explica-lo feito da permanencia no fogar de irmáns e irmás do primoxénito casado.

En definitiva, a parroquia de Cereixa resposta ás características xerais da familia rural da Galicia centro-oriental: alta porcentaxe de grupos domésticos complexos, número elevado de fillos, peso específico de copresidentes e presencia pouco significativa de criados, son variables que configuran un modelo cultural de organización familiar troncal, claramente condicionado pola especificidade e limitacións do sistema agrario imperante.

Toda esta estructura agropecuaria, demográfica e familiar desenvolvíase baixo un sistema señorial feudal que cargaba á comunidade campesiña con gravames como a a luctuosa, consistente na entrega ó señor dunha res cando falecía o cabo da casa; este verdadeiro tributo en especie, aínda que se pagaba de tanto en tanto, tiña unha incidencia brutal nas economías campesiñas, así como os dezmos, o voto de Santiago, ou a alcabala viexa pagada de antigo á condesa de Lemos.

Asemade, os veciños habían de facer fronte ó pagamento da primicia para o sostemento da fábrica parroquial, a cal chegaba a un montante total de 50 ferrados de centeo, distribuídos en función da riqueza dos veciños; así, os de maior caudal contribuían con dous ferrados de centeo, os de mediano a ferrado e medio, outros 
a ferrado e cuarto, a seis octavos e a cinco, e os de menos posibilidades a catro e a dous oitavos. O pagamento das primicias non sempre se levaba a cabo dentro dos prazos o que obrigou ó crego de Cereixa a proceder a unha reorganización deste gravame que quedou reflectida na documentación parroquial, amosándonos a poboación existente daquela ( 70 veciños ou cabos de casa, fronte ós 52 do ano 1753) e a forte presencia dun comunitarismo campesiño:

Hago saber á los vezinos en el refertorio de la misa del primer dia festivo nombren entre ellos dos hombres buenos inteligentes y desinteresados, y arreglen la contribución y el tanto de Primicia que cada uno debe pagar con respecto a los vienes que posea y demás facultades. Memoria de la Primicia: Nogueiras (9 vecinos), Lende (3), Zapateira (2), Aquelcabo (2), Guntiñas (7), Areas (3), Casa de la Sierra (1), Rayros (6), Puente y Corbal (14), Molinos (1), Barrio Falcon (5), Cimadevila (17) ${ }^{13}$.

\section{O ESPACIO: UNHA APROXIMACIÓN A ESCALA MICRO}

O territorio parroquial defínese primeiramente coma unha paisaxe agrícola que xera un modelo espacial concreto, reflexado na microtoponimia que recollemos sinteticamente a continuación:

Cadro 2

Microtoponimia da parroquia de Cereixa (recollida a partir da enquisa etnográfica e da consulta do Catastro de Ensenada, 1753).

Sistema de explotación agrícola: A Veiga, Trigais, A Cha de Nogueiras, A Cha de Castro, A Cha de Ramos, A Agra de Arriba, O Chao, O Chao das Cortiñas, o Agro, Cenoira, Cortiña de Alende, A Aira, A Viña Vella, A Viña Longa, Os Currais, Chouselas, O Covallo.

Monte baixo e bosque: A Devesa, A Castañeira, O Souto, Carballedo, O Carpancedo, O Amieiro, Punxedo, A Carqueixa, O Toxal, A Xesteira, O Cachón, A Costa, A Serra, Moncai, Monteixón, Mompedroso, Penelas de Vilarello.

Zonas de humedal, prado: A Lama, A Lamela, Lamasboas, Os Lameiros, O Sobrado, Entrerríos, A Ínsua, Foncerbeiras, Bourallos, O Gorgorelo, o Rego de Amieiros, Caldelas, A Torrente.

Parcelación do terrazgo: O Cerrado, O Pechado, a Cancela, O Canceleiro, O Igrexario, Muradella.

Actividades extractivas: As Areas, As Forgas, O Barredo, A Pedreira, As Grovias, O Escourial, O Pozo do Lago, As Pozas do Barro.

${ }^{13}$ ADL. San Pedro de Cereixa, Fábrica, Libro I (anos 1715-1941). Anotación persoal do crego, ano 1790 .

Cuadernos de Estudios Gallegos, Tomo LII, Fascículo 118, Santiago 2005. (Págs. 117 - 172) 
Outras actividades: O Limpadoiro, O Moíño, Albariza, O Pozo dos Cabalos, O Liñar, o Pombar, Vías de tránsito: o camiño da Serra, Rairos, a Retorta, a Calzada, a Ponte Vella, O Lombao, A Cabarca, a rúa da Fonte, As Cadeiras

Ruínas arqueolóxicas: San Lourenzo, O Castro da Lende, A Coroa (O Castro)

Límites Parroquiais: A Cruz, a Cruz do Mollón

Abandonos: Lamas, Cavagares, O Corbal.

Outros microtopónimos: A Lucenza, O Cazapedro, Vilarello, A Rañoá, A Raposa, Mioqueira, O Belido, As Lampazas, O Piteiro.

A parroquia de Cereixa modeliza a paisaxe agraria localizada nos pequenos vales abertos de Galicia, conformando unha unidade fisiográfica cerrada que, centrada arredor dun río e limitada polas súas divisorias, presenta toda a variedade de posibilidades naturais que demanda o sistema agrario tradicional (Ballesteros e.p.: 13-30). Deste xeito, artellouse un sistema gradual de explotación do solo no que a parte inmediata ás casas acolle pequenas cortiñas nas que se plantan legumes, hortalizas e frutais diversos, ás que seguen no entorno, a un nivel máis baixo, as terras de labradío (agras, chas e chaos). Na zona inferior da pendente e nas áreas húmidas á marxe do río e afluentes, atópanse as terras de pasto para o gando. Por riba das casas atópase o bosque, o monte e mailo inculto.

Asemade, o sistema de parcelación do terrazgo vén dado por unha considerable presión demográfica sobre o espacio, adicado a un policultivo propio dunha economía familiar de subsistencia, sen implicacións comerciais. A estructura agaria vixente en Cereixa a mediados do século XVIII, baseada na secuencia de ortos, cortiñas, agras, prados e monte perviviu ata a década de 1960, garantindo as colleitas de cereal (agras e monte comunal) necesarias para a subsistencia. Os prados e as cortiñas incrementaban a producción alimenticia e de forraxes destinadas ó vacún en rexime de estabulación intensiva.

\section{Cartografía mítica da parroquia}

Tentaremos agora inferir e demostrar nesta segunda parte do traballo a existencia dunha cartografía mítica que se sobreimpón sobre o espacio agrícola existente coma o resultado dun proceso de semantización do espacio, de apropiación simbólica do medio por parte da comunidade campesiña tradicional ${ }^{14}$. Neste senso, os

\footnotetext{
${ }^{14}$ A investigación desta cartografía mítica, reivindicada hai xa anos (Criado Boado 1986) estáse a desenvoltar a escala de toda Galicia (Arqueoloxía da Paisaxe e o mito galego: un caso significativo, tese de Doutoramento en preparación do noso compañeiro A. Arizaga Castro) co gallo de rexistrar esa paisaxe imaxinada, reflectida na microtoponimia e no folklore, que está a piques de desaparecer nos vindeiros anos.
} 


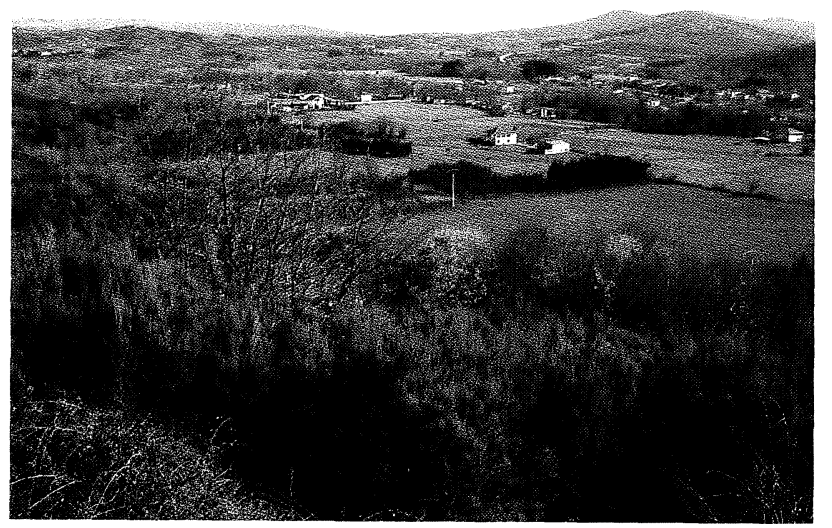

Figura 7.- Panorámica da parroquia dende A Coroa/O Castro. Cereixa axústase perfectamente ó modelo ideal dun espacio agrario tradicional en Galicia (segundo Ballesteros e.p.).

límites da parroquia son ritualizados seguindo unha práctica común no rural galego (Llinares e Vázquez Varela 1990) mediante a reutilización das modorras como marcos monumentais ou a erección de cruces de pedra, que ademais de marcos serven de símbolo apotropaico para a comunidade perante os inimigos exteriores. Este perímetro define un microespacio no que o eixo vertebrador vai sé-lo río Saa, o cal divide (e une) a parroquia en dúas zonas, emprazándose a meirande parte das aldeas ó carón deste curso fluvial e dos correspondentes vados para cruzalo. $\mathrm{O}$ núcleo de poboación orixinario estableceríase no actual barrio da Ponte, onde se erguía a primitiva igrexa, centro simbólico da parroquia, referente en torno ó cal se organiza o poboamento, feito que explica a microtoponimia dos lugares de Alende (ó outro lado do río en relación con este centro simbólico) e Cima de Vila.

Esta igrexa, probablemente románica, é citada sempre nas Visitas Pastorais para remarca-lo seu penoso estado de conservación:

Hemos reconocido lo deteriorada q se halla y la mala situación que tiene, mandamos se remueba en lo posible otra vez, a mejor sitio y q pa ello el cura paro ${ }^{\text {co }}$ cobre el caudal que tienen la $y g l^{a}$ y cofradía del $S t^{o}$ Sacramento, dejando solamente lo preciso para sus funciones. Haga entender a los feligreses la obligación que tienen de concurrir con el peonaje, y carretos necesarios, y busque maestro que ajuste la bra, haciendo antes plan de ella, e que se nos se presentará nates de otorgar la escritura ${ }^{15}$.

${ }^{15}$ ADL, San Pedro de Cereixa, Fábrica, Libro I (anos 1715-1941). Visita Pastoral de 1802. 
Situación que se subsana baixo o patrocinio do señor xurisdiccional da parroquia, o bispo de Lugo, nese mesmo ano:

En Onze de Marzo de mil och y dos se comenzó a quebrantar piedra para la construcción de la nueba Iglesia de San pedro de Cereyxa y se finalizó en ultimos d Agosto del mismo año; fue Domingo Ant ${ }^{o}$ Arca cuya estructura ajustó $p^{r}$ veinte mil re $e^{s}$ de los que el señor Felipe Fozara y señor de Lugo dio trece mill, Josef Benito Pérez nat. de esta y en el presente cura de San Salvador de Villauje, y arregló dio mil reales. La Fábrica contribuyó con cinco mil y la cofradía del $\mathrm{Sm}^{\circ}$ Sacramento contribuyo con otros mil, y los feligreses hicieron los carretos, y en el dia dos de septiembre la bendicio el infra escrito cura y dijo la primera misa con otros señores Sacerdotes, q asisitieron a la Solemnidad, y para que conste lo anoto aqui como cura q presente estoy en ella a 6 de septiembre de mil ochocientos $y$ dos ${ }^{16}$.

A nova igrexa parroquial, que permanece na actualidade, constitúe un edificio de mampostería, revocado, de nave rectangular con cuberta de madeira a dúas augas, ábside cuadrangular con teito de madeira a catro vertentes e sacristía na cabeceira, máis baixa, a tres vertentes. No interior destaca o arco de acceso ó presbiterio de medio punto, lousado e espadana con dous vans. Sen dúbida, o apoio do Bispado de Lugo e o seu papel como símbolo do seu poder señorial, explica en boa media a calidade e capacidade desta construcción que contrasta co resto de igrexas parroquiais da contorna.

Malia diso, o máis chamativo desta fundación ex novo é a elección do emprazamento, nunca posición central na xeografía de Cereixa, a rentes dunha carballeira centenaria, coñecida como $\boldsymbol{O} \boldsymbol{s}$ Carballos, espacio comunal empregado como campo da festa profano, servindo de marco natural e espacio ritual para a celebración de festividades ígnicas como a Noite dos Cepos na véspora do San Brais. Probablemente a elección desa nova ubicación viñese dada polo genius loci dun espacio, sancionado pola tradición campesiña, que compría cristianizar dacordo coa relixiosidade oficial.

Sexa como for, este espacio dual, antagónico e complementario, conformado pola arquitectura sacra da igrexa parroquial -co seu adro, verdadeiro espacio comunitario para as reunións dos veciños-e polo espacio natural e ritual dos Carballos (verdadeiro monumento salvaxe), constitúe de feito o centro simbólico desa carto-

${ }^{16}$ ADL, San Pedro de Cereixa, Fábrica, Libro I (anos 1715-1941). Anotación persoal do crego. Ano 1802.

Cuadernos de Estudios Gallegos, Tomo LII, Fascículo 118, Santiago 2005. (Págs. 117 - 172) 
grafía mítica, o eixo do mundo domesticado, do eido da cultura, que se contrapón ás áreas periféricas do monte, naturais, nas que agroman as ruínas de tempos pasados, habitadas por seres míticos coma os mouros.

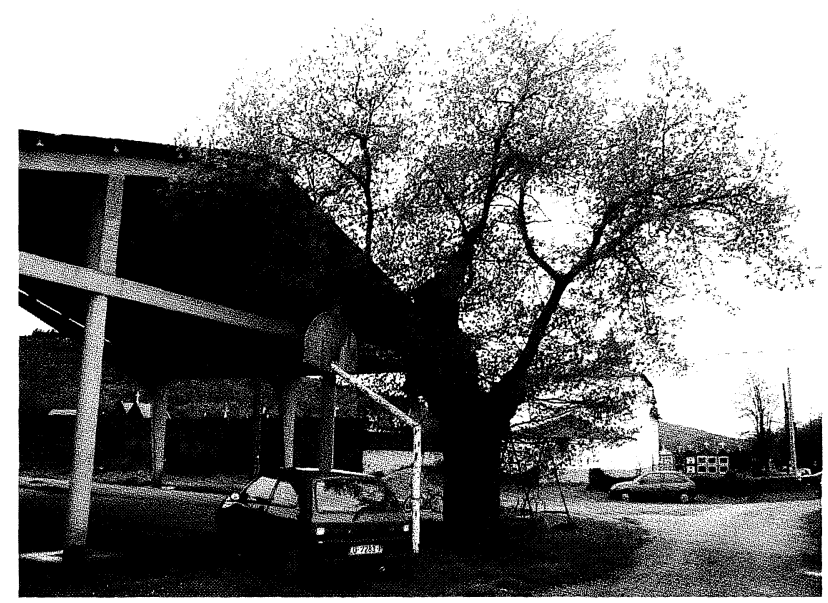

Figura 8.- Os Carballos - actual campo da festa- e maila igrexa nova de 1802, centro simbólico da parroquia.

\section{A Coroa/O Castro e o castro da Lende/San Lourenzo: espacios do imaxinario colectivo}

Neste espacio non domesticado, periférico da parroquia, cómpre destaca-lo papel xogado por estes dous monumentos protohistóricos como escenarios simbólicos. Os castros, tralo seu abandono coa romanización pasan a seren espacios periféricos na paisaxe rural tradicional, converténdose nunha área máis de captación de recursos económicos. Non obstante, o seu papel de resto material dun pasado pagán non pasou inadvertido para a sociedade tradicional nin para a Igrexa, xa nos intres temperás da cristianización do noso país. Velaí que se construísen capelas no cumio de castros, e se celebren romarías, procesións e cerimonias de carácter relixioso sobre estes asentamentos protohistóricos.

O castro preséntase, xa que logo, non coma un espacio de culto nin adoración senón coma soporte simbólico, lugar de encontro entre o mundo oculto e o mundo visible, centro privilexiado para a circulación entre seres humanos e sobrenaturais (Mandianes 1984: 71-2). Como sinala Fernández de Rota, os espacios comunitarios da parroquia (fragas, monte comunal, encrucilladas) veñen sendo un espacio da natureza escasamente domesticada, unha área periférica menos frecuentada, de 
aí que se presenten como lugares segmentados con identidade propia, co seu propio mundo representativo e simbólico. A este respecto, o castro aparece perfectamente delimitado no seo da parroquia, sendo normalmente un espacio veciñal, ritual, pragmático, simbólico e representativo, que remarca a forza intergrupal e a cohesión da comunidade (Fernández de Rota 1984: 152-55).

Estas ruínas arqueolóxicas vencéllanse ó universo mítico dos mouros, antepasados imaxinarios dos que existe un interesante universo lendario dos que dan fe as lendas recollidas por nós nos últimos anos e que gardan moita semellanza con referencias folklóricas publicadas e procedentes de áreas veciñas coma $\mathrm{O}$ Incio (González Reboredo 1971) e O Courel (Alonso del Real 1983).

\section{O Castro/A Coroa}

Desde o camiño da serra hai unha cadea de ouro e un balde co que collian auga os mouros no río das Areas.

No Castro téñense visto cobras mamando dos tetos dunha vaca.

\section{O Castro da Lende/San Lourenzo}

Disque no San Lourenzo vivian os mouros.

$O$ castro era un fuerte antiguo, dos romanos, os celtas que utilizaban o castro, $e$ daquela, desde ei comunicaban por morse con Salcedo, con Chavaga, con Castrosante... O castro está atrincherado porque son serras moi cortadas e cavaban para que se lles fixera máis dificil subir; daquela a guerra era a paus, todo era bayoneta naquiles tempos.

Os mouros posiblemente son os moros; aqui reinou a mourindá nunha época e, claro, toda esa xente albergábase en sitios coma o castro, onde había bosque, metíase no bosque porque estaban acostumbrados a vivir no bosque... Houbo a guerra da mourindá e moitas outras porque viñeron generaciós que se peleaban unhos cos outros; houbo os celtas, celtíberos, godos, visigodos, os romanos; todos foron botados a paus. Hai unha historia grande diso...

i:Teño oído que os mouros tiñan unha cadea e unha caldeira de ouro que baixaba desde o castro hasta o río e que con ela subían a auga pro castro e depositábana no pozo que elí ha, que lle chaman o Burato dos Mouros.

Dicían que habia unha cadea de ouro que baixa hasta o río e que de noite se escoitaba ruxir a roldana.

Contaban que os mouros mataran unha nena por eli; seica se perdera no castro; os pais buscárona e cando berraban por ela ¡Mariquiña, Mariquiña! escoitábase a voz dunha moura que dicía:

Cuadernos de Estudios Gallegos, Tomo LII, Fascículo 118, Santiago 2005. (Págs. 117 - 172) 
¡Ni que Mariquiña ni que Maricuela, que tu Mariquiña está en mi cazuela!

No castro dicían que había unhos pitiños que aparecían e desaparecían. Un día unha rapaza seguiu ós pitiños e desapareceu tamén; fórona buscar e berraban ¡Mariquiña, Mariquiña!, e neso que se escoitou unha voz, dalá do fondo:

¡Que Mariquiña, ni que Maricuela,

por ser lengoreta está en la cazuela!

Dicían que no camiño do castro se vía roupa tendida ó sol nos silveiros e unha galiña con pitos pequenos e rara vez vírase unha moura peinándose, co pelo negro coma o pez e moi longo que lle chegaba ás coxas; e que nun cerrar e abrir de ollos xa desaparecía todo, a moura e as pitas.

Tamén contaban os vellos que eli se vía un home no burato dun castiñeiro e que dispois desaparecía; e dician que eran os mouros. Iso son cousas de antes, cando a xente non tiña que facer, non había televisión, e que habian facer, contar historias, inventar contos.

Dicíannos de pequenos que nas zanxas das Grovias estuvera a Arca de Noé cando fora o do diluvio.

\section{O Castro de Chavaga}

Do castro haiche moitas leiendas; contaban que habia unha cadea de ouro entre o Castro e Sindrán e que a descubririan as patas das ovellas pois non estaba moi profundo.

Dende o Castro hai unha cadea de ouro hasta á Meda, e descubrirana as patas das ovelllas.

No Castro hai dúas trabes baixo da terra, unha de ouro e outra de veneno; de encontrar primeiro a de veneno estouparía todo.

$\mathrm{Na}$ Coroa víanse colchas de seda a secar e ó chegar alá desaparecian, porque eran dos mouros que vivian baixo a terra no Castro.

No Castro tendian a roupa os mouros e cando chegaban os de Chavaga desaparecian porque estaban encantados.

O meu pai cría na existencia dos mouros; diciame que 'si que che existen os mouros, viven debaixo da terra; ás veces, ó voltar da feira de Monforte viñas cun home que resultaba ser un mouro e desaparecía de súpeto cando entraba dentro do Castro'.

Os mouros vivían alá dentro debaixo da terra; a xente críao, como non, ó encontralas vasixas arando na Coroa comprobaban que era certo que vivían dentro da terra.

De pequeno unha señora vella contoume varios contos de mouros; un era a historia da fonte do Refoxo. Din que unha rapaciña fora buscar auga á fonte do Refoxo, onde a auga xorde como fervendo a borbotóns da terra. Unha vez na fonte aparecéuselle 
unha moura que lle deu unha bolsiña coa condición de non abrila antes de chegar á casa. A rapaciña colleuna e marchou; pero claro, púdolle a curiosidá, e deu en abrir a bolsa e viu que o de dentro era carbón, e tirou con ela. Sen embargo, ó chegar á casa decatouse de que lle quedara un pouquichiño no pliegue da roupa e resulta que era unha onza de ouro. Ó día siguiente volveu á fonte a ver se quedaba o resto do ouro e apareceuselle a moura de novo, que lle dixo:

-Por non terme obedecido quedarás baixo a terra a ferver.

E por iso a auga da fonte sae fervendo a borbotóns do chao.

Non imos abordar o trasfondo de todo este conxunto de lendas, xa que a día de hoxe dende a Antropoloxía coñécese moi ben a funcionalidade e sentido das mesmas (véxanse os traballos de Criado Boado 1986, Llinares García 1990; Aparicio Casado 1999 ou Ayán e Ameixeiras 2002). Nembargantes, cómpre subliñar que os nosos informantes teñen unha concepción moi clara da articulación dos asentamentos castrexos na paisaxe, sendo conscientes da súa intervisibilidade e función de dominio e control do espacio; deste xeito, a cultura popular, na súa explicación do mundo castrexo como fenómeno histórico non deixa de coincidir plenamente neste aspecto coas conclusións ás que se teñen chegado dende a perspectiva da Arqueoloxía espacial ou Arqueoloxía da Paisaxe. Os paisanos relacionan este vencellamento entre os castros da comarca coa súa funcionalidade estratéxica e militar, dentro dunha percepción histórica cíclica baseada na sucesión de diferentes razas belicosas. Outro tema interesante vén sendo o vencellamento dos castros cos cursos fluviais e coa figura da serpe ${ }^{17}$. De feito, a aba meridional dámbolosdous castros, ben soleadas, con abundante pedra para mante-la calor, e nas que se cultivaron viñas noutro tempo, son zonas nas que tradicionalmente abondaron as cobras, chegando a utilizarse o unto da cobra pra facer un remedio que che era moi bo contra a reuma.

\section{O PATRÓN DE RACIONALIDADE: RELIXIOSIDADE OFICIAL E CULTURA POPULAR}

Ó longo do presente texto tracexamos unha sintética panorámica arqueohistórica do proceso de conformación dunha paisaxe cultural, que nos permitiu poñer en

${ }^{17}$ Para unha análise do tema da serpe no folklore galego véxase o traballo interpretativo de F. Criado (1986).

Cuadernos de Estudios Gallegos, Tomo LII, Fascículo 118, Santiago 2005. (Págs. 117 - 172) 
evidencia a sucesión de diferentes estructuras espaciais, fidel reflexo de sucesivas formacións socioculturais. No punto de chegada do noso percorrido puidemos achegarnos ó universo mental do campesiñado, iniciando unha nova xeira que tentaremos completar neste último apartado do noso traballo, mediante unha descripción densa que nos permite enxergar o patrón de racionalidade manexado pola sociedade rural tradicional que dotou de sentido á cartografía mítica que describimos con anterioridade.

Para acadar este obxectivo, verdadeira finalidade da nosa investigación, desenvolvemos unha aproximación que maximice as aportacións de diferentes disciplinas (Historia Rural, Antropoloxía Histórica, Historia das Mentalidades) coa aplicación conxunta de diversas ferramentas metodolóxicas (nomeadamente o baldeirado documental de fontes, a enquisa etnográfica, a análise iconográfica e a Historia Oral).

Este patrón de racionalidade non constitúe un modelo estático senón que se trata dunha cosmovisión definida historicamente na que se misturan rupturas e continuidades, cultura popular e intromisións do sistema de saber-poder eclesiástico. A documentación coa que contamos, nomeadamente as Visitas Pastorais á parroquia na segunda metade do século XVIII, corroboran o xa apuntado nas últimas décadas pola investigación modernista galega encol do universo mental do campesiñado galego no Antigo Réxime (Dubert 1994; Saavedra 1994: 275-390). Deste xeito, atopámonos cunha parroquia rural na que o clérigo rector desempeña un rol e amosa unhas actitudes próximas ó campesiñado, que se enfrontan directamente co proceso de civilización dos costumes potenciado dende o Concilio de Trento polas autoridades eclesiásticas.

As sucesivas visitas mostran unha escandalosa y remarcable inobediencia ${ }^{18}$ por parte do cura párroco que non pon o coidado esixido tanto na loita contra as crenzas paganizantes dos aldeáns coma no alonxamento con respecto deles. Velaí os requerimentos do arcipreste de Santalla de Rei, representante do Bispo de Lugo, nas súas visitas á parroquia de Cereixa:

Mandamos renobarse cada ocho dias alomenos las Sagrdas Hostias. Por ningún caso se confiese fuera de la Iglesia, ni a las mugeres con confesionarios de mano, sino fixos, y cerrados con regilla espesa. No se reciva en el conferio evitando qualq ${ }^{r}$ sombra de simonía, ô codicia, con apercibimiento de rigurosas penas a los Contraventores, de $q^{e}$ debe darnos razon este Cura $R^{o r}$ como asim ${ }^{o}$ de los Clerigos que, sin precisos motivos,

${ }^{18}$ ADL, San Pedro de Cereija, Fábrica, Libro I (anos 1715-1941). Visita pastoral de 1794.

Cuadernos de Estudios Gallegos, Tomo LII, Fascículo 118, Santiago 2005. (Págs. 117 - 172) 
ô con indez concurran â Romerías y ferias, y de los que asistan a las Ferias desprovistos sin el debido ornato y dect vestido, contra los que procedermos con rigor ${ }^{19}$.

Comisionamos a dicho Cura p paminar a las Comadres ô Parteras de su Parroq ${ }^{a}$ , e instruirlas debidamente $p^{a}$ los casos de agua de socorro y $p^{a}$ examinar en doctrina Xrsitiana a los mozos de primeras letras, escusándolos de los que para su defecto, o malas costumbres, no sean dignos. Esperamos del celo de este Cura $R^{o r}$ lo continuara en el aseo y $d z^{a}$ de su Iglesia ${ }^{20}$.

Teniendo noticia de que en algunas Iglesias del Obispado se saca el Stmo Sacramento con motivo a temporal, ú otro, se manda que por ningun pretexto se saque, si no por la Process" del Corpus.. Cuide con el devido zelo que los feligreses no trabaxen en las fiestas en que esta prohibido, sino acasso de absoluta necess. y con expressa licencia ${ }^{21}$.

Esta loita oficial a prol da cristianización das devocións e crenzas populares, sen dúbida incidiu notablemente na cosmovisión campesiña, mais en certa medida fracasou rotundamente perante a capacidade de sincretismo relixioso dun campesiñado que mantivo determinados rituais nalgúns casos ata ben entrado o século XX, e noutros deica a actualidade.

Para adentrármonos na microhistoria deste universo mental, complexo e fluctuante na longa duración, empregaremos como punto de partida a análise iconográfica das advocacións relixiosas expostas no retábulo maior da igrexa parroquial de Cereixa, verdadeiro panteón relixioso que nos facilitará a comprensión desta cosmovisión vivida e reactualizada polo cristianismo campesiño.

\section{O panteón relixioso da parroquia}

O retábulo maior da parroquia de Cereixa, de estilo neoclásico e con pinturas murais no testeiro do século XIX, alberga esculturas de San Lourenzo, Xesús, San Pedro, San Xosé e San Antonio de Padua. Compleméntase o aparato iconográfico do templo (datable formalmente no século XVIII) con outros dus retábulos menores caracterizados por unha fasquía propia da arte popular; o retábulo dereito, salomónico, expón as imaxes de San Sebastián, San Brais, o Apóstolo Santiago, San Roque e San Xerome, mentres que o esquerdo abrangue un conxunto de devocións femininas, con esculturas de Santa Bárbara, A Nosa Señora do Rosario, Santa María e Santa Tareixa de Xesús.

\footnotetext{
${ }^{19}$ Ibid. Visita Pastoral de 1771.

${ }^{20}$ Ibid. Visita Pastoral do 6 de agosto de 1772.

${ }^{21}$ Ibíd. Visita Pastoral de 1782.
} 


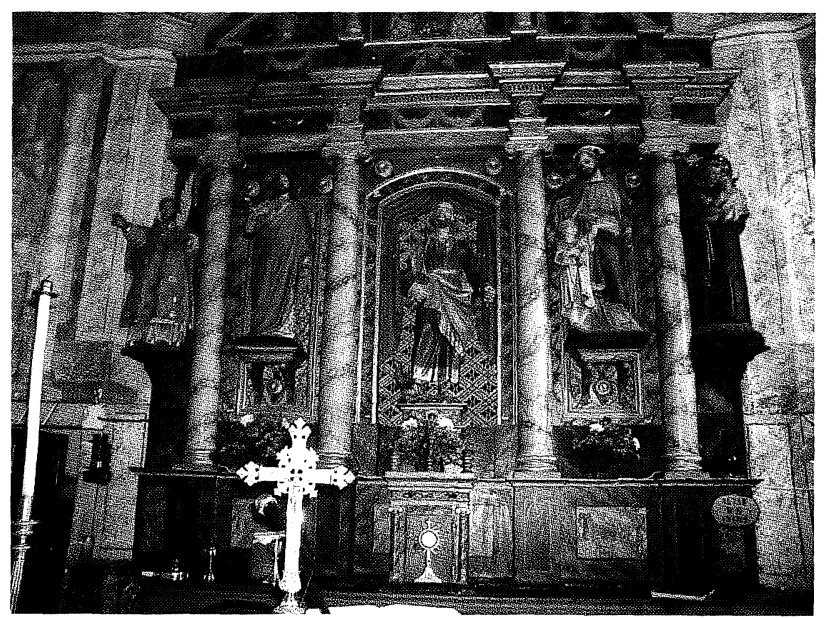

Figura 9.- Retábulo maior da igrexa de Cereixa. De esquerda á dereita: San Lourenzo, O Nazareno, San Pedro, San Xosé e San Antonio de Padua.

Esta amalgama de imaxes, aparentemente caótica, representa ben ás claras o proceso vivido dende o século XVI nas parroquias rurais galegas no eido das devocións relixiosas, no que se constata un doble proceso: por unha banda, a imposición de novos cultos (A Nosa Señora do Rosario ou Santa Tareixa de Xesús) e por outra, a reactualización de santos de fonda tradición popular xa dende a Idade Media. De feito, coñecemó-la estratexia seguida polo clero postridentino no tocante á arte relixiosa para achegar ó campesiñado ó dogma establecido en Trento. Nas representacións iconográficas da época (verdadeiro catecismo gráfico para ós labregos) reactualízanse santos moi populares ós que se dota de virtudes deica o momento descoñecidas, como Santa Bárbara, advogada da boa morte, ou San Sebastián, escudo perante a peste (Saavedra 1994: 306).

Se be é certo que foron as autoridades eclesiásticas o verdadeiro axente promotor de moitas destas devocións populares, cómpre remarca-la presencia de cultos locais, tradicionais e fondamente enraizados entre o campesiñado. Como sinala P. Saavedra (1994: 352): A pesar de que la jerarquía eclesiástica controló tenazmente los cultos parroquiales y de que el santoral y la onomástica pueden cosiderarse un espejo de ese dirigismo del clero, el universo de las devociones presenta una cierta complejidad, pues el campesinado nunca perdió del todo la iniciativas.

A este respecto, o que alcumamos como panteón relixioso de Cereixa reflicte de xeito moi significativo a confluencia desta triple dinámica. En primeiro lugar, a 
presencia como patrón da parroquia, dende a súa orixe, de San Pedro, un dos santos máis antigos no culto hispánico (s. VI) e o que encabeza o meirande número de parroquias en Galicia, trala Virxe María, e o máis representado nos retábulos barrocos; a pesares de ocupar unha posición central no retábulo maior, non conta cunha destacable devoción popular no caso que nos ocupa. Pola contra, meirande incidencia vai te-la ofensiva contrarreformista, coa imposición do culto da Virxe do Rosario a finais do século XVI, e que actualmente vén sendo oficiosamente a Patrona da parroquia, na honra da cal se celebran as festas patronais a comezos de Outubro.

Parellamente a esta relixiosidade oficial pervive un culto popular tradicional centralizado nas devocións de San Brais e San Lourenzo que posúe un interesantísimo trasfondo histórico e antropolóxico, ata o punto de dotar de sentido á paisaxe mítica que temos identificado anteriormente.

A continuación analisaremos ó miúdo este proceso ambivalente no que conflúen a relixiosidade oficial e mailo cristianismo campesiño.

\section{A oficialidade contrarreformista. A Nosa Sra. do Rosario e as confrarías}

A parroquia de San Pedro de Cereixa, ó atoparse baixo o señorío do Bispo de Lugo, preséntase coma un exemplo paradigmático da aplicación da relixiosidade contrarreformista, que devalou tendo como eixos vertebradores, a ofensiva polo culto eucarístico (Santísimo Sacramento), o incentivo do culto mariano e a potenciación das confrarías como marco para o control do asociacionismo religioso tanto no mundo urbano como rural (González Lopo 1997).

Neste contexto debemos encadra-lo culto á Nosa Señora do Rosario, espallado mercede á predicación dominica, á loita contra o protestantismo e ós intereses políticos do Papado (a festa celébrase o 7 de outubro en conmemoración da batalla de Lepanto en 1571). En Galicia trataríase dun culto potenciado con enorme éxito polas autoridades eclesiásticas como así o amosa o seguinte dato: de non existir ningunha confraría no noso país adicada a esta advocación nos anos 1547-48 pasouse a 398 (o 66,8 \% do total) en 1750 (González Lopo 1997: 300-1).

Polo tanto, trátase dun culto ex novo, patrocinado pola Igrexa, e que irrumpiu con forza no patrón de relixiosidade dos habitantes da nosa parroquia, pero que non partía dunha tradición anterior, ó contrario do que acontecía con San Brais que si gozaba do fervor popular. Este último feito levou ó Bispado de Lugo á organización da Cofradía de San Blas para encauzar este antigo culto, como así o manifestan as súas Constituciones, Dispuestas por D. Joseph Taboada y Camba. Aunque se toleró asta el presente tiempo por la costumbre introducida de los cofrades deella 
y de los señores Obispos autorizaron, habiéndolo hecho el Istmo. Juan Saenz de Buruaga Obpo y $S^{r}$ deeste Opdo ${ }^{22}$.

Estas constitucións, de mediados do século XVIII, tentaron normativizar unha corporación relixiosa de longa tradición (temos constancia da súa existencia en 1689), regulando os comportamentos, os xestos e rituais a celebrar dentro do recinto sacro, de acordo coa práctica relixiosa oficial:

Que el día tres de Febrero en que la Santa Iglesia haze conmemoración de San Blas, a cuio honor dedica cultos esta devota Cofradía (manteniendose con el caudal asta el presente) se cante una misa, a maior gloria de Dios con asistencia de ocho Sazerdotes; siendo es preziso, y limitado numero de hermanos de tal estado, y q estos tengan obligación de asistir a Solemnizar la Missa con sobriedad y la compostura correspondiente en la procesión $n^{23}$.

Que el Mayordomo à cuio cargo está el cuidado dela zera de esta Cofradía lo tenga, y observe sin nota de omisso, repartiendo a tiempo, sin vozes, ni estrepito en la Iglesia, a todos los cofrades que se allen presentes en ellas, al prinzipiar la Missa Cantada, a cada uno su vela, y no mas, porque algunos quieren tomar dos o tres, con pretexto de que lo hacen en nombre de los ausentes suios, siendo esto conocido desfalco de la Caridad de la Cofradía y los que las rezivieren cuiden no quebrantarlas, ni las enziendan zerca de la bendición de la Sagrada Ostia, manteniendolas enzendidas asta acavada la fumpzion, y en la procesión saian con todo conzierto en dos Filas, y no a pelotones, para cuio gobierno se nombrará uno o dos, siendo necesario que cuiden; $y$ cada uno entregarla después la vela que hubiese rezivido sin fraude, al Maiordomo, $\hat{o}$ Recaudador para su Custodia ${ }^{24}$.

A iniciativa da Igrexa enfrontábase de cheo coa devoción e maila relixiosidade popular, que tiña as súas propias canles de expresión, como é o caso da noite dos Cepos, celebración ritual de véspera conservada na actualidade.

\section{$O$ «San Blas»: a festa dos vellos}

San Brais ${ }^{25}$, bispo de Sebaste na Armenia no século IV e martirizado en época de Diocleciano, ó que se lle atribúen poderes taumatúrxicos (en especial contra os

\footnotetext{
${ }^{22}$ ADL, San Pedro de Cereija, Cofradías, Cofradía de San Blas, Libro n I (Anos 1689-1791), Constituziones de la Cofradía de San Blas (18 de xaneiro de 1765).

${ }^{23}$ Ibid. $6^{a}$ Constituzion.

${ }^{24}$ Ibid. $7^{a}$ Constituzión.

${ }^{25}$ Este santo é titular de 2 parroquias e a súa celebración cae no 3 de febreiro. En Monforte soben os devotos a San Vicenzo do Pino levando a bendicir cintas azuis os homes e rosas as mulleres,
} 
males da gorxa e males de oídos), é un santo moi popular en Galicia, o que se explica polo éxito acadado no NW hispánico polos mártires paleocristiáns (Santa Mariña, San Lourenzo, Santa Lucía, San Cristovo...) que foron utilizados pola Igrexa para cristianizar cultos de orixe prerromana (Castro Pérez 2001).

$\mathrm{Na}$ Terra de Lemos trátase dun culto moi popular (xunto con Santa Bárbara ${ }^{26}$, tamén presente nun dos retábulos da parroquia), potenciado polos condes de Lemos no século XVI ó traeren de Italia reliquias do santo. Esta advocación relixiosa, na parroquia de Cereixa, pode ser considerada coma o culto máis representativo dentro da cosmovisión do campesiñado. No Memorial de los Cofrades ${ }^{27}$ podemos observa-la orixe xeográfica dos devotos que procedían dun grande número de parroquias da zona, polo que poderiamos falar dunha advocación local de amplo culto sancionado pola tradición popular.

A súa importancia remárcase por ser considerada como a festa dos vellos, que ven de moi antiguo, moito antes da Virgen do Rosario. Como nos contou un home da parroquia de 90 anos de idade:

O San Blas era a festa propia, de sempre, era o Patrón xa en tempos antiguos. Deixouse de facer cando eu era pequeno. Era moi nombrada e viñan ofrecidos e todo, doutras parroquias. Despois ibase a Mosteiro, á festa do San Blas. Habia a costumbre de queimar os Cepos de carballo seco nos Carballos, a noite de véspora. Para apañar os cepos iban os homes con carros a Pinel e a Brence, e de paso enchíanse os carros de nabos e outras cousas. Faciase unha pota de arroz e xa habia festa. Érache boa festa porque se comía o da matanza, en troques no Rosario comprábase todo fóra. Índa recordo a copla que se lle cantaba:

Meu Santo San Blas de Viana,

feito de pau de amieiro,

irmao das miñas angrellas,

criado no meu ribeiro.

e rosquillas e melindres, nunha tradición que se remonta ó século XVI. No Baixo Miño o prato típico é a cacheira, o bandullo do porco, a lingua, a pa e as chourizas. En Compostela van os devotos á igrexa de San Paio e o sacerdote ponlle unha vela en forma de U na gorxa (Ferro Ruibal et al. 1992: 171-2).

${ }^{26}$ Nesta bisbarra proliferan as capelas adicadas á esta santa, protectora contra as treboadas, moi comúns nos meses estivais na Depresión de Lemos (Saavedra 1994: 322).

${ }^{27}$ Atópanse rexistrados individuos das parroquias de Fornelas, Brence, Castroncelos, Castrosante, Eixón, Santalla de Rei, Saa, Pinel, Chavaga, A Parte, Sindrán, Lamaigrexa, Veiga, e Ribas Pequenas. (ADL, San Pedro de Cereija, Cofradías, San Blas, Libro n² 2, anos 1736-1762).

Cuadernos de Estudios Gallegos, Tomo LII, Fascículo 118, Santiago 2005. (Págs. 117 - 172) 
Se ben é subliñable a súa importancia no calendario litúrxico, xa que precedía ó tempo de penitencia da Cuaresma (de aí o dito popular Vamos, mozas, a San Brais, que festas non quedan máis), moito máis remarcable é o feito de tratarse dun fito festivo sobranceiro no calendario agrícola da comunidade. En pleno inverno, nun período no que a vida se centraba na casa, no núcleo familiar (a diferencia do verán, intre álxido dos traballos comunitarios) e no que se desenvolvían as matanzas do porco, actividade básica na súa economía de subsistencia, a festa do San Blas (tamén chamada festa das cacholas) potencia os lazos do asociacionismo veciñal, ritualizados a véspera na alcumada Noite dos Cepos.

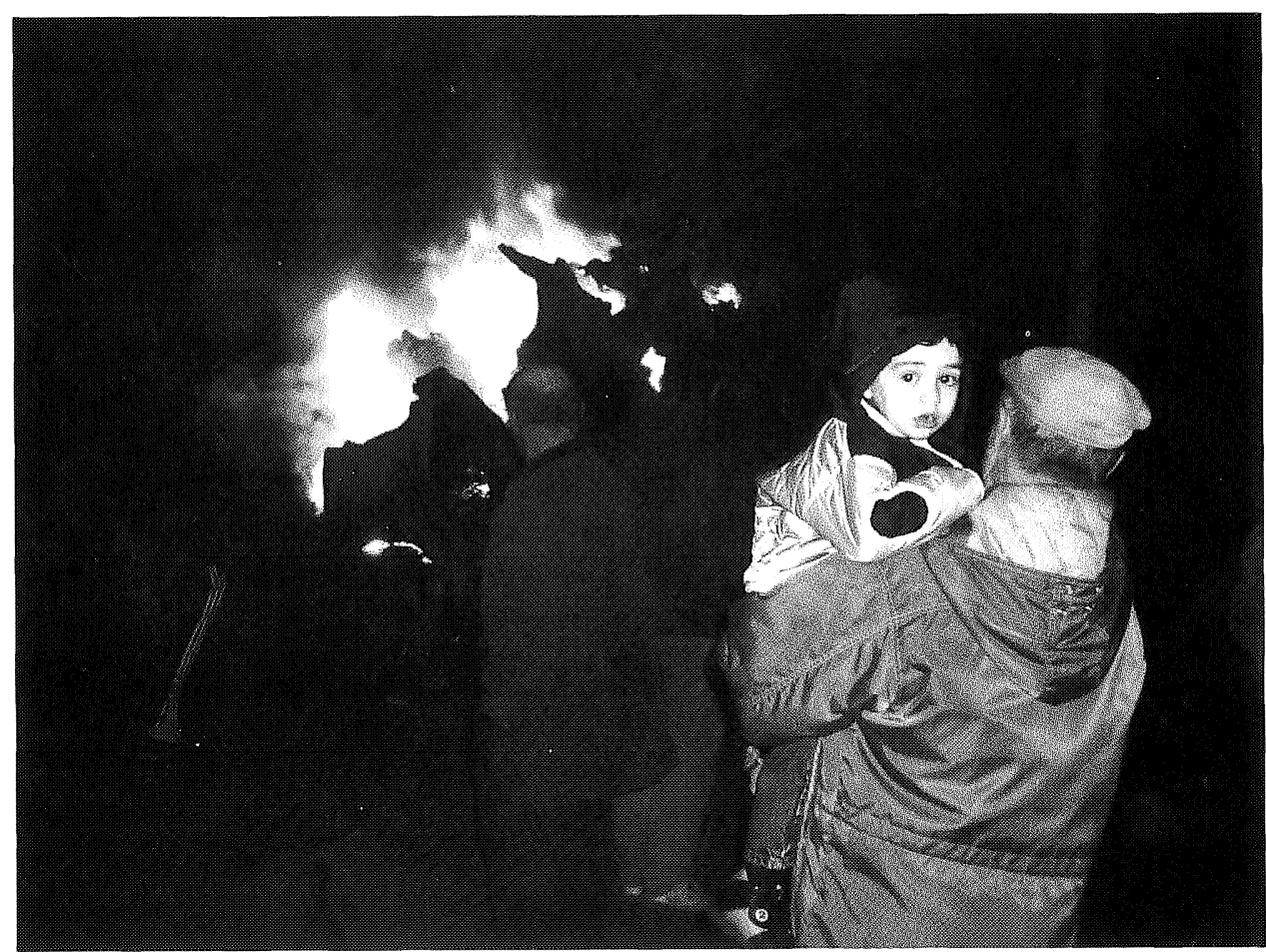

Figura 10.- A cerimonia popular tradicional: celebración da Noite dos Cepos en Os Carballos (febreiro de 2004)

Trátase dunha festividade ígnica que nos remite ós chamados folións de véspera nos que se facían, a noite anterior á festa do santo, lumieiras, ou se percorría con fachos espacios ritualizados como castros (Ayán e Ameixeiras 2002). No noso país esta práctica era bastante común (Taboada 1980; Bouza Brey 1982) destacando na 
zona de estudio os folións da Ribeira Sacra do Miño ${ }^{28}$, só conservados na actualidade nas parroquias de Castelo (Taboada) e Vilelos (O Saviñao), e maila procesión de San Sebastián en Castro Caldelas (Ourense).

Na celebración da Noite dos Cepos, contra a que nada puido facer a Igrexa, a pesares do seu control a través da confraría de San Blas, conflúe o lume, nun ritual propiciatorio e purificador; reivíndicase o traballo colectivo, símbolo da autofirmación da parroquia como comunidade (os lugares da parroquia turnábanse para organiza-la festa seguindo unha orde preestablecida, sancionada pola tradición) e ritualízase claramente o centro simbólico da parroquia, Os Carballos, actual campo da festa que ata a década de 1980 estaba ocupado por unha carballeira centenaria.

Finalmente, cómpre destaca-lo feito de que esta festividade considérase coma a cristianización de antigas festividades prerromanas, como viña sendo no mundo céltico a festa do Imbolc, que marcaba o paso da metade do inverno, o medrar dos días (a iso se refiren os ditos populares en chegando o San Brais, pon pan e viño na alforxa, que día non faltará ou o día de San Brais ten dúas horas máis) sendo substituída no calendario cristián pola Candelaria e o San Brais (García Quintela 2003).

Esta festa popular, abandoada antes da guerra, recuperouse a comezos da década de 1970, manténdose, á súa vez, a tradicional misa con procesión polo adro da igrexa (protagonismo compartido pola imaxe da Virxe do Rosario e do San Brais), a exposición do santo e o ofrecimento dos devotos de cintas azuis e rosas, así como a bendición de cirios e de alimentos.

\section{Vicisitudes dun santo hidróforo: San Lourenzo, do castro ó río, e do río á igrexa}

O culto ó San Brais mantívose deica a actualidade. Outra sorte correu a devoción popular ó San Lourenzo, de enorme importancia noutro tempo na paisaxe cultural da parroquia de Cereixa. De feito, no retábulo maior da igrexa consérvase unha imaxe deste santo da que é tradición que veu dunha capela, actualmente en ruínas, ubicada sobre o castro da Lende, por ese motivo tamén coñecido como San Lourenzo. Eu mesmo téñolle escoitado ó meu avó a historia do santo:

${ }^{28}$ X. M. Vázquez Rodríguez (1997-98: 296-99) no seu excelente traballo cataloga tódolos folións de véspera tradicionais nos concellos de Chantada, Carballedo, Saviñao e Pantón. En 82 casos tiñan lugar nun monte ou outeiro (máis da metade do total de folións), celebrándose en 9 casos en castros (case o $8 \%$ do total dos folións). 


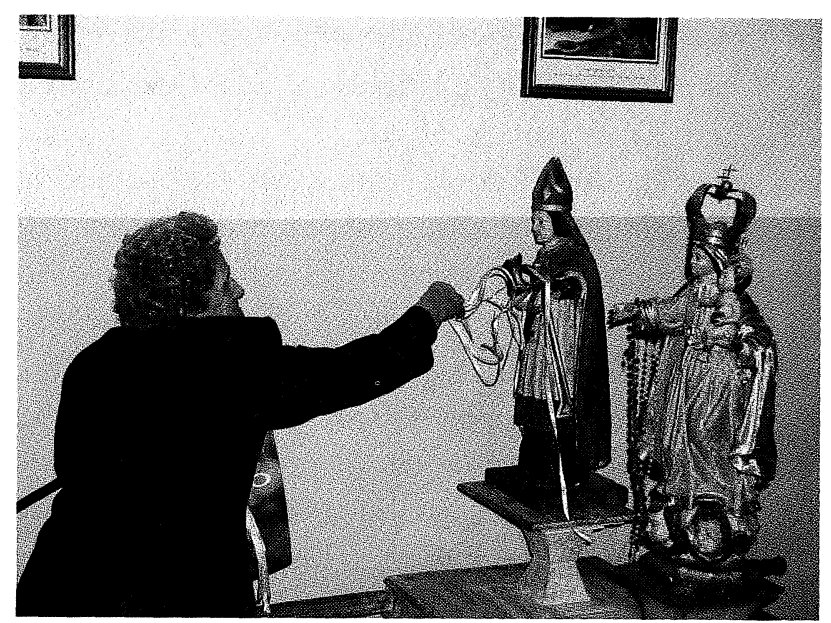

Figura 11.- Imaxes da Virxe do Rosario e do San Brais, despois da procesión arredor da igrexa e ofrenda de cintas rosas e azuis que son bendecidas durante a ceremonia na igrexa.

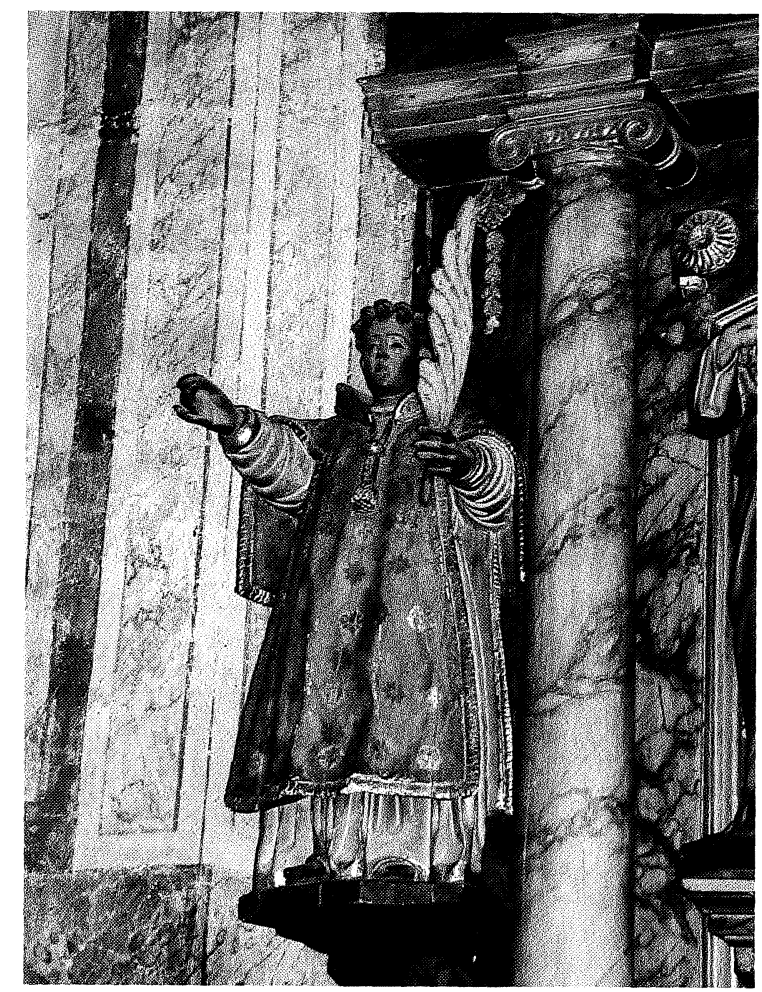

Figura 12.- Imaxe do San Lourenzo, procedente da capela do castro da Lende. 
O San Lourenzo trouxérono os curas dali, do castro, para a iglesia, pero o santo marchaba e íba po castro, quería seguir ali, así que se lle fixo outra capela no castro. A miña abuela contaba das rogativas que se facian cando habia sequía; que un ano que non chovera nada fórase en procesión desde o castro hasta o río e ó molla-lo santo no río comezou a chover, salvando as colleitas. Eu xa non a recordo, a capela, que inda se verán aínda os muros. A pedra levouse dali para as casas da Lende.

Como suliñamos anteriormente, San Lourenzo, martirizado en Roma no s. III, é un dos santos máis antigos no culto hispánico (século $\mathrm{V}$ ) e dos de meirande tradición en Galicia, sendo titular de 73 parroquias e de numerosas capelas, moitas delas emprazadas sobre castros. Trátase dun mártir paleocristián que, como ten demostrado F. Bouza Brey en dous fermosos traballos (Bouza Brey 1963, 1982a) foi reinterpretado polo cristianismo campesiño coma un santo hidróforo, considerado como portador de auga (en virtude da tradición haxiográfica que decribe o seu martirio queimado vivo nunha parrilla), substituíndo a antigos númenes ou divindades prerromanas (Bouza Brey 1982a: 236-9).

Este vencello popular do santo co lume levou a que fose utilizado polas comunidades campesiñas en rogativas e ritos impetratorios da choiva nos meses estivais (a festa do santo é o 10 de agosto) que en moitos casos conlevaban a inmersión da imaxe do santo, como así se facía na parroquia de Ferreiros (Cuntis) ou en San Lourenzo de Ouzande (A Estrada) (Bouza Brey 1963: 131-2).

En Cereixa, a enquisa etnográfica permitiunos reconstruir a existencia desta antiga tradición, que ritualiza a importancia da auga neste val do Saa, como fan tamén as lendas de mouros no imaxinario popular. Por outra banda, a análise arqueolóxica abordada facilitounos non só a documentación dun castro cristianizado, senón tamén recupera-lo sentido orixinal dun monumento esencial na cartografía mítica da parroquia. Deste xeito, trátase dun exemplo máis da apropiación simbólica destes poboados protohistóricos por parte do campesiñado, proceso sancionado positivamente polas autoridades eclesiásticas, que autorizaron a construcción de capelas adicadas ós mártires paleocristiáns (San Cibrao, Santa Mariña, Santa Cristiña, San Lourenzo) sobre estes recintos (Aparicio Casado 2002: 81-4).

A antigüidade do culto corrobórase pola presencia do microtopónimo San Lourenzo, referido ó castro da Lende, no Catastro de Ensenada. No cumio deste San Lourenzo aínda se conservan os alicerces da capela, que orixinarimaente debeu ser de planta rectangular cun porche de entrada na fachada. Nunha casa do barrio da Lende, foron reutilizadas nunha porta as xambas e o dintel da capela, no que se conserva unha inscrición que nos remite a unha reforma decimonónica da ermida: AVE MARIA/ESTE CORPO LO HIZO (Figura dunha cruz) D JOSE BR EN 1876. 


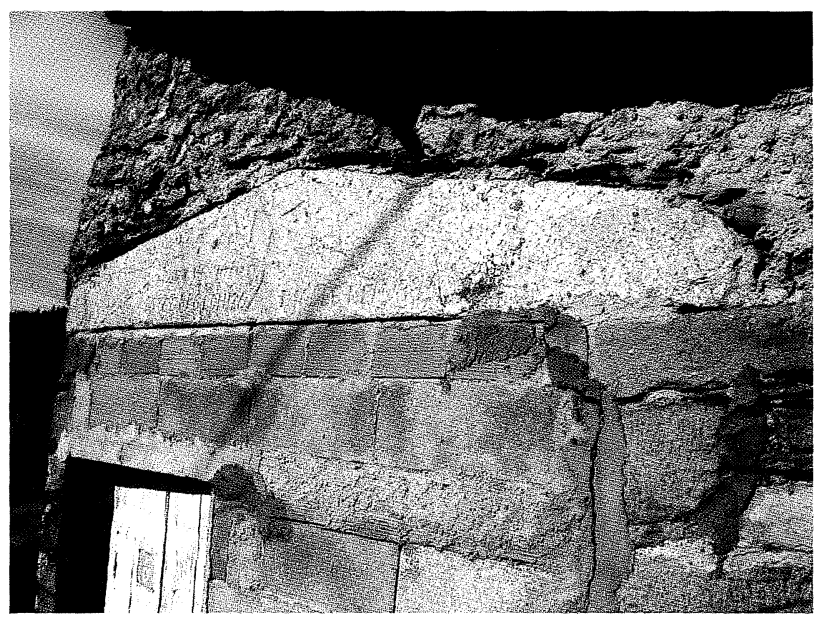

Figura 13.- Portada da capela de San Lourenzo, reutilizada nunha casa da aldea da Lende.

Chegamos así á fin do noso percorrido. A análise arqueohistórica e antropolóxica a escala microespacial realizada no noso traballo dá como resultado a nosa comprensión dun espacio medioambiental, a bacía baixa do río Saa, e o proceso de conversión dese espacio natural nunha paisaxe cultural, modelizada finalmente pola sociedade rural tradicional. Esta comunidade dotou de sentido ó seu espacio social, dacordo cun patrón de racionalidade que puidemos interpretar polo miúdo, ata o punto de identificar a estructura mítica inherente ó mesmo, a cal artellaba a vida cotiá, a calendarización festiva e agrícola, unha apropiación simbólica concreta dos espacios e maila configuración do panteón religioso, baseado no sincretismo do cristianismo campesiño.

Recollemos sinteticamente no seguinte cadro esta estructura mítica, actualmente en vías de desaparición.

Cadro 3

Estructura mítica da parroquia de Cereixa.

\begin{tabular}{|c|c|c|c|c|c|c|c|c|}
\hline Advocación & $\begin{array}{c}\text { Tipo } \\
\text { de culto }\end{array}$ & Data & Espacio & $\begin{array}{c}\text { Categoría } \\
\text { espacial }\end{array}$ & Comunidade & $\begin{array}{c}\text { Orixe } \\
\text { do culto }\end{array}$ & Forza & Animal \\
\hline S. Brais & $\begin{array}{c}\text { Mátir } \\
\text { paleocristián }\end{array}$ & $\begin{array}{c}3 \mathrm{de} \\
\text { febreiro }\end{array}$ & Os Carballos & Natural/Central & labregos & Prerromana? & Lume & vaca \\
\hline S. Pedro & Apóstolo & $\begin{array}{l}29 \mathrm{de} \\
\text { xuño }\end{array}$ & Igrexa & Relixioso/central & cristiáns & altomedieval & $\begin{array}{l}\text { Corpus } \\
\text { Christi }\end{array}$ & \\
\hline S. Lourenzo & $\begin{array}{c}\text { Mátir } \\
\text { paleocristián }\end{array}$ & $\begin{array}{l}10 \text { de } \\
\text { agosto }\end{array}$ & $\begin{array}{c}\text { Castro da } \\
\text { Lende }\end{array}$ & $\begin{array}{c}\text { Mítico/ } \\
\text { periférico }\end{array}$ & mouros & altomedieval & auga & cobra \\
\hline $\begin{array}{l}\text { Virxe do } \\
\text { Rosario }\end{array}$ & $\begin{array}{c}\text { Advocación } \\
\text { contrarreformista }\end{array}$ & $\begin{array}{c}7 \mathrm{de} \\
\text { outubro }\end{array}$ & Igrexa & Relixioso/central & católicos & s. XVI & Rosario & \\
\hline
\end{tabular}




\section{CONSECUENCIAS}

Precuramos como primeiro obxectivo do noso traballo elaborar unha reconstrucción arqueohistórica da xenealoxía e proceso de conformación dunha paisaxe cultural a escala local, desenvolvendo unha estratexia de investigación interdisciplinar que partiu da Arqueoloxía da Paisaxe como marco teóricometodolóxico. Dende estes presupostos amosamos os diferentes patróns espaciais que se foron sucedendo ó longo do tempo pola bacía baixa do río Saa, configurando cada un á súa maneira unha paisaxe que reflicte non só un patrón de subsistencia senón tamén o patrón de racionalidade desas sociedades.

Esta reconstrucción arqueolóxica aplicouse á súa vez ó estudio do último estadio dese proceso, o que dotou de sentido á paisaxe rural tradicional. Asumindo un enfoque interdisciplinar acadamos un primeiro achegamento ó patrón de racionalidade, unha contextualización cronólóxica -decote nada doada-das crenzas populares, ó imaxinario colectivo da comunidade campesiña, que condicionou non só o modelo de poboamento senón tamén a estructura agropecuaria ou o artellamento dos espacios simbólicos e rituais.

Chegar a aprehender, aínda que fose de lonxe, ó sentido desa paisaxe cultural, é a razón de ser deste estudio microhistórico que, como tal, tamén precura incardinar un espacio, local e aparentemente insignificante, coa superestructura socioeconómica e cultural de cada período histórico polo que pasou o rural galego no seu conxunto. Mais, como calquera práctica discursiva, este texto non é inocente e agocha unha triple reivindicación. Por unha banda, independentemente dos resultados da investigación, que poden ser -ou non- satisfactorios para o lector, cremos que é necesaria a utilización da análise arqueolóxica como ferramenta esencial para desenvolver estudios diacrónicos sobre as formas culturais concretas das paisaxes culturais do pasado. A rendabilidade deste tipo de aproximacións dende a Arqueoloxía da Paisaxe está fóra de toda dúbida, despois dos resultados de estudios a escala comarcal feitos no NW (Criado et al. 1992, Rodríguez Fernández 1994; Santos et al. 1997; Fernández Mier 1999), que rachan coa compartimentación estanca dunha disciplina acadecimista que consagra conceptos tan absurdos como o de disciplinas auxiliares de la Historia.

Participando desta estratexia de investigación, tentamos levar adiante un proxecto semellante, minimizando a escala de análise. Á hora de achegarnos ó noso obxecto de estudio, isto é, cómo cambia a paisaxe concebida coma un producto sociocultural na longa duración, acotamos o espacio no que se plasma ese proceso de construcción social da realidade. Somos conscientes de que un estudo sobre a Idade do Ferro, por poñer un exemplo, non pode partir unicamente do rexistro dun só castro. 


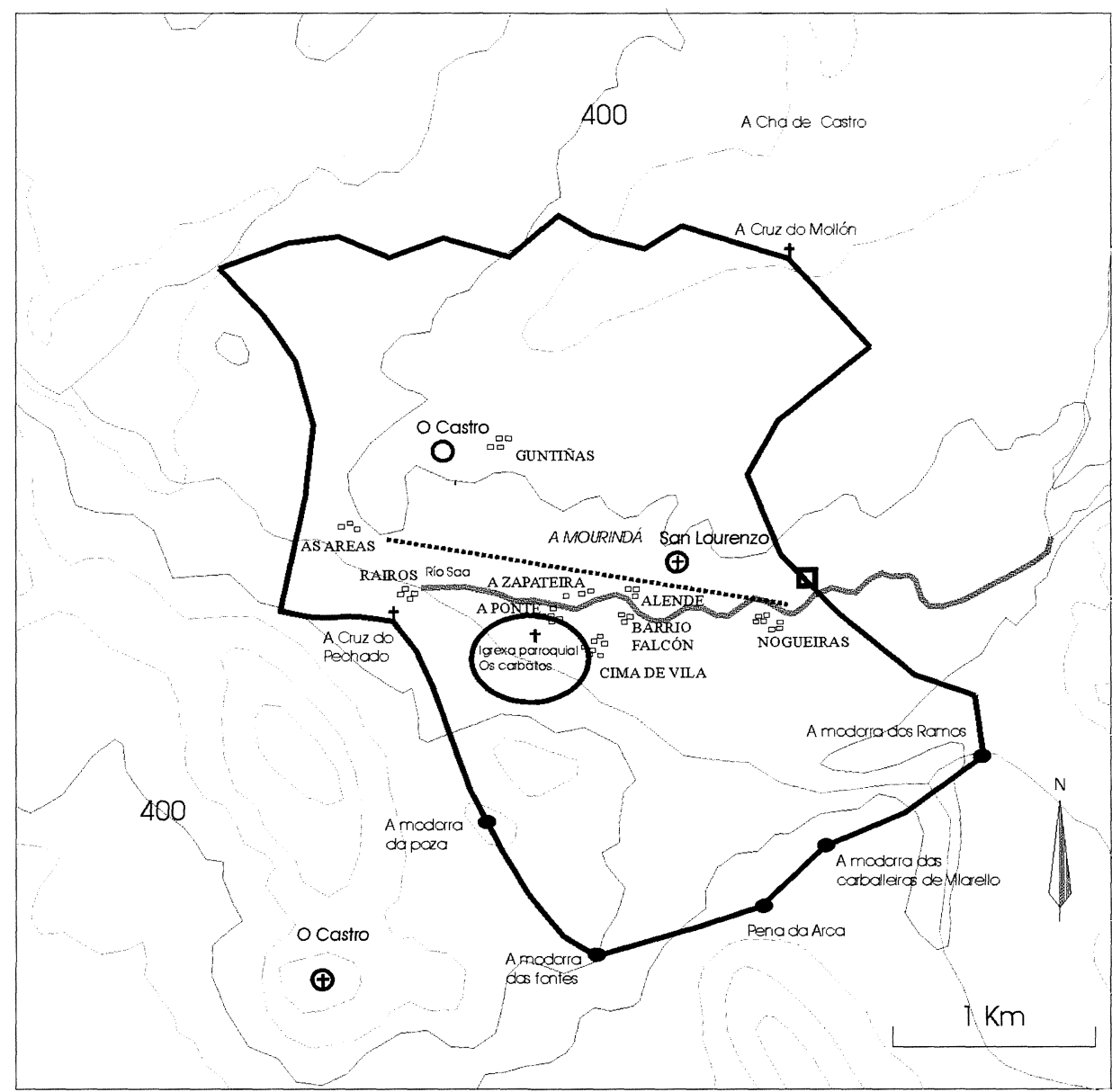

+ Cruces de término

$\oplus$ Castros cristianizados.

- Túmulos megalíticos reutilizados como marcos parroquiais.

- O Escoural actividade mineira romana reutilizada como límite parroquial.

O río Saa como eixo vertebrador da paisaxe.

- Centro simbólico da parroquia

..... Límite entre o espacio cultural, central, cristián e campesiño, e o espacio mítico, pagán, e periférico, habitado polos mouros

Figura 14.- Sinalización simbólica do espacio parroquial e cartografía mítica de Cereixa. 
O efecto zoom, fornece unha perspectiva que nos permite enxergar ó detalle os procesos que artellan o discurso das grandes sínteses xerais, isto é, a problemática das categorías espacio-temporais, as rupturas e continuidades, a dicotomía cultura popular-cultura das elites, tradición e innovación, etc.

Velaí o noso segundo anceio: reivindicar os estudios microhistóricos, sen caír en pretenciosiadades inxenuas, idealistas e provincianas. Así, por exemplo, o estudio microespacial de dúas vilas altomedievais galegas (Portela e Pallares 1998) fornece unha información preciosa e preciosista para a nosa comprensión histórica dese período, das relacións da comunidade medieval co medio, o artellamento do territorio, o patrón espacial e a configuración do espacio social. Vén sendo unha perspectiva lexítima que complementa a información que nos poidan dar a transcrición de centos de cartularios e tombos monásticos ou estudios cuantitativos de índole demográfica ou socioeconómica.

Asemade, apostamos decididamente por unha necesaria, máis que nunca, etnoarqueoloxía da paisaxe rural tradicional galega. Dicía Rigoberta Menchú que ela non se vía capacitada para ser antropóloga do seu propio pobo, porque non quería concebilo coma un obxecto de estudio. Pode ser certo. Nós, como arqueólogos, tratamos con testemuños mudos, tentando un achegamento, a partires da cultura material, cara á simboloxía e ó patrón de racionalidade das comunidades do pasado. Dentro de poucos anos xa non poderemos ser antropólogos do noso pobo, perante a ausencia de individuos que coñezan o código visual e simbólico da paisaxe social construída pola sociedade tradicional, e só teremos unha paisaxe cultural fosilizada, como a analisada nos primeiros capítulos deste texto.

O modelo de espacialidade que reconstruímos no noso traballo, esa cartografía mítica, esa cosmovisión, só se mantén na mente dun fato de campesiños, de máis de 80 anos de idade. De non termos rexistrado todo ese imaxinario colectivo, en breve só poderiamos achegarnos a unha ruína arqueolóxica, como a capela esborrallada do San Lourenzo, sen poder comprender nunca o verdadeiro sentido desa manifestación cultural. Sinceramente prefiro ser antropólogo antes que arqueólogo da nosa identidade.

Finalmente, somos conscientes das críticas que se veñen facendo deste tipo de prácticas historiográficas de carácter microhistórico, de precurar universalidades no ámbito do local. Anticipándonos a elas, facemos nosas as fermosas verbas do escritor asturiano Xuan Bello ${ }^{29}$, autor dunha Historia Universal da súa aldea natal, 2004).

${ }^{29}$ Xavi Ayén: Xuan Bello. Reportaxe en Magazine, Suplemento Dominical (28 de marzo de 
Paniceiros: Ya escribió William Blake, el visionario inglés, que el poeta es el que sabe ver el universo en un grano de arena. Tolstoi, más pragmático, aconsejaba al escritor emergente que si quería cantar a la tierra inmensa, cantase a la aldea donde habia nacido. Esta capacidad de ir de lo local a lo universal, y viceversa, es simplemente la cultura, la necesidad de explicar el mundo. Lo que le pasa a un hombre le pasa a todos los hombres. Lo mismo vale Dario que su esclavo, porque para los dos brilla en el cielo la misma luna sangrienta.

\section{AGRADECEMENTOS}

Ós meus pais, Eloína Vila Regueiro, de Cereixa, e Xulio Ayán Vázquez, de Chavaga. Á miña irmá, Silvia. A Iván do Turín, a Xoel do Izquierdo, a Juanjo do Xan María de Piño, a Ana da Diosa, a Sonia, a Rafa e a Leo, porque somos nós. A tódolos habitantes de Cereixa, os que viven na parroquia e os que están fóra. A don Antonino, párroco de Cereixa, falecido durante a elaboración deste traballo, e á quen lle tería gustado ver impresas estas páxinas. Ós meus compañeiros e amigos do renovado Grupo de Investigación en Arqueoloxía da Paisaxe e nomeadamente a Felipe Criado, polo seu maxisterio e apoio continuo e cotián. A David Barreiro, pola lectura e corrección do texto. A Anxo Rodríguez Paz pola axuda no aparato gráfico.

Á memoria dos meus avós, Jesús Vila Saavedra e Antonio Ayán Vázquez, canteiros da terra, que me ensinaron a ler nas pedras.

\section{FONTES DOCUMENTAIS}

\section{Arquivo Histórico Provincial de Lugo}

Catastro de Ensenada, Parroquia de San Pedro de Cereija, Interrogatorio General, Libro Personal de Legos.

Catastro de Ensenada, parroquia de S. Juan de Chavaga, Interrogatorio General.

Catastro de Ensenada, villa de San Pedro de la Puebla del Brollón, Interrogatorio General.

\section{Arquivo Diocesano de Lugo}

San Pedro de Cereija, Cofradías, Cofradía de S. Blas, Libro n I (anos 1689-1791).

San Pedro de Cereija, Cofradías, Cofradía de S. Blas, Libro n ${ }^{\circ}$ II (anos 1732-1762).

San Pedro de Cereija, Cofradías, Constituciones de la Cofradía de San Blas (ano 1762).

Cuadernos de Estudios Gallegos, Tomo LII, Fascículo 118, Santiago 2005. (Págs. 117 - 172) 
San Pedro de Cereija, Fábrica, Libro ${ }^{\circ}$ I (anos 1715-1941).

San Juan de Chavaga, Cofradías, Libro de la Cofradía del Santísimo. Acuerdo entre los curas de Cereija y Chavaga y vecinos de las feligresías sobre delimitación de propiedades y diezmos (3 de julio de 1785).

FERNÁNDEZ DE VIANA Y VIEITES, J. I. 1994. Colección diplomática del monasterio de Santa María de Ferreira de Pantón. Lugo: Servicio de Publicacións da Deputación Provincial de Lugo.

FERREIRA PRIEGUE, E. 1988. Los caminos medievales de Galicia. Anexo nº 9 del Boletín Auriense. Ourense.

LUCAS ÁlVAREZ, M. 1980. El tumbo de San Julián de Samos. Santiago: Obra Social Caixa Galicia.

\section{BIBLIOGRAFÍA}

ALONSO DEL REAL, C. 1983. Notas etnográficas de O Courel. Boletín do Museo Provincial de Lugo. T. 1: 131-140.

AMOR MEILÁN, M. 1980. Puebla del Brollón. En Geografia de Galicia. Volumen IX. Tomo $2^{\circ}$ : 651-660. A Coruña. Ed. Galegas.

ANDRADE CERNADAS, J.M. 1996. Las Villae en la Galicia de la mutación feudal: el caso de Celanova. En A guerra en Galicia. O rural e o urbano na historia de Galicia: 277-290. Santiago de Compostela. Asociación Galega de Historiadores.

APARICIO CASADO, B. 1999. Mouras, serpientes, tesoros y otros encantos. Mitología popular gallega. Cadernos do Seminario de Sargadelos, 80. Sada. Ediciós do Castro.

APARICIO CASADO, B. 2002. A sociedade campesiña na mitoloxía popular galega. Biblioteca de divulgación. Serie Galicia, no 27. Santiago. Universidade de Santiago de Compostela.

AYÁN VILA, X.M. 1997. Aproximación á cultura castrexa e á romanización no concello de A Pobra de Brollón (Lugo). Traballo Academicamente Dirixido. Universidade de Santiago. Inédito.

AYÁN VILA, X.M. y AMEIXEIRAS, F. 2002. Mámoas, castros e tesouros: a Mourindá nas terras de Cuntis. En Ayán Vila, X. M. (Coord.): Pasado e futuro de Castrolandín (Cuntis, Pontevedra). Unha proposta de recuperación e revalorización. TAPA (Traballos en Arqueoloxía da Paisaxe) 29: 143-68. Santiago. IEGPS (CSIC-XuGa).

BALIÑAS PÉREZ, C. 1992. Do Mito á Realidade. A definición social e territorial de Galicia na Alta Idade Media (Séculos VIII e IX). Coordenadas Monografías, 18. Santiago de Compostela. Fundación Universitaria de Cultura.

BALLESTEROS ARIAS, P. e.p. La Arqueología en la Gasificación de Galicia: El paisaje agrario. CAPA (Cadernos de Arqueoloxía e Patrimonio). Santiago. IEGPS (CSIC-XuGa). 
BARROS, C. 1993. La contribución de los Terceros Annales y la Historia de las mentalidades: 1969-1989. En González Mínguez, C. (Ed.). nt:La otra historia: sociedad, cultura y mentalidades: 87-118. Bilbao. Univ. de Bilbao.

BELLO DIÉGUEZ, X.Mª; CRIADO BOADO, F. e VÁZQUEZ VARELA, J.M. 1982. Sobre la cultura megalítica y los caminos antiguos en Galicia. El Museo de Pontevedra, t. 36: 143-63. Pontevedra. Museo de Pontevedra.

BOHUIER, A. 1979. La Galice: Essai geographique d'analyse et d'interpretation d'un vieux complexe agraire. La Roche-sur-Yon.

BOUZA ÁLVAREZ, J.L. 1990. Religiosidad contrarreformista y cultura simbólica del Barroco. Biblioteca de Dialectología y tradiciones populares, 25. Madrid. CSIC.

BOUZA BREY, F. 1963. Ritos impetratorios da choiva en Galiza: a inmersión dos sacra e os vellos cultos hídricos. En Actas do primeiro Congresso de Etnografia e Folklore (promovido pola Câmara Municipal de Braga, 22-25 de Junho de 1956). Vol. I: 125-38. Lisboa. Biblioteca Social e Corporativa.

BOUZA BREY, F. 1982. El espíritu de la tierra en Galicia y las ceremonias ígnicas lustrales del campo gallego. En Bouza Brey, F.: Etnografia e Folklore de Galicia. Vol 2: 105-10. Vigo. Edicións Xerais de Galicia.

BOUZA BREY, F. 1982a. Los mitos del agua en el Noroeste hispánico. En BOUZA BREY, F.: Etnografia e Folklore de Galicia. Vol 2: 219-39. Vigo. Edicións Xerais de Galicia.

BURGUIÉRE, A. 1995. L'anthropologie historique et L'École des Annales. En Barros, C. (Ed.): Historia a Debate, III: 127-37. Santiago. Historia a Debate D.L.

BURKE, P. 1990. La cultura popular en la Europa moderna. Madrid. Alianza.

CASTRO LÓPEZ, R. 1929. Reseña histórico descriptiva de la parroquia de Vilar de Ortelle y su comarca y de los monumentos protohistóricos del partido de Monforte de Lemos. Con una relación de los principales santuarios, leyendas, supersticiones y otras curiosidades antiguas del país. Monforte de Lemos. Imprenta de F. Rodríguez.

CASTRO PÉREZ, L. 2001. Sondeos en la arqueología de la religión en Galicia y norte de Portugal. Trocado de Bande y el culto jacobeo. Vigo. Servicio de Publicacións da Universidade de Vigo.

CRIADO BOADO, F. 1986. Serpientes gallegas: madres contra rameras. En Bermejo Barrera, J. C.: Mitología y Mitos de la Hispania prerromana, 2: 241-74. Madrid. Akal.

CRIADO BOADO, F. 1989. Asentamiento megalítico y asentamiento castreño: una propuesta de síntesis. Gallaecia, 11: 109-37. Sada. Ediciós do Castro.

CRIADO BOADO, F. (dir.). 1991. La Arqueología del Paisaje en Galicia. El área Bocelo-Furelos entre los tiempos paleolíticos y medievales. (Campañas de 1987, 1988 y 1989). Arqueoloxía/ Investigación, 6. Santiago. Xunta de Galicia.

CRIADO BOADO, F. 1993. Visibilidad e interpretación del registro arqueológico. Trabajos de Prehistoria, 50: 39-56. Madrid. CSIC.

CRIADO BOADO, F. 1999. Del Terreno al Espacio: Planteamientos y Perspectivas para la Arqueología del Paisaje. CAPA (Criterios y Convenciones en Arqueología del Paisaje), 6. Santiago. Grupo de Investigación en Arqueoloxía da Paisaxe. 
CRIADO BOADO, F. e VILLOCH VÁZQUEZ, V. 1998. La monumentalización del paisaje: percepción y sentido original en el megalitismo de la Sierra de Barbanza (Galicia). Trabajos de Prehistoria 55 (1): 63-80. Madrid. CSIC.

CRIADO BOADO, F. e BALLESTEROS ARIAS, P. 2002. La Arqueología rural: contribución al estudio de la génesis y evolución del paisaje tradicional. En Congreso de Ingeniería Civil, Territorio y Medio Ambiente ( $1^{\circ} .2002$. Madrid, 13,14 y 15 de febrero de 2002): 461-479. Colegio de Ingenieros de Caminos, Canales y Puertos, Comisión de Medio Ambiente. Madrid. Colegio de Ingenieros de Caminos, Canales y Puertos.

DAVID, P. 1947. Etudes historiques sur la Galice et le Portugal du 6è au 12è siècle. Paris-Lisboa. Institute Français au Portugal.

DUBERT GARCÍA, I. 1994. A Cultura popular na Galicia rural do Antigo Réxime, 1500-1830: Ofensivas e resistencias. Grial, t. 32, n. 122 (abr.-xuño 1994). 235-54.

FERNÁNDEZ DE ROTA, J. A. 1984. Antropología de un viejo paisaje gallego. Madrid. CIS, Siglo XXI.

FERNÁNDEZ MIER, M. 1999. Génesis del territorio en la Edad Media: arqueología del paisaje y evolución histórica en la montaña asturiana: el valle del río Cigüeña. Oviedo. Universidad de Oviedo.

FERNÁNDEZ OXEA, X.R. 1968. Santa Marta de Moreiras: monografia dunha parroquia ourensán. Vigo. Castrelos.

FERRO RUIBAL, X. (dir.) 1992. Diccionario dos nomes galegos. Vigo. Ir Indo.

FILGUEIRAS REY, A. y RODRÍGUEZ FERNÁNDEZ, T. 1994. Túmulos y petroglifos. La construcción de un espacio funerario. Aproximación a sus implicaciones simbólicas. Estudio de la Galicia Centro-Oriental: Samos y Sarria. Espacio, Tiempo y Forma, 7: 211-253. Madrid. UNED.

FRAGUAS FRAGUAS, A. 1978. Geografía de un lugar. En: Miscelánea de geografía de Galicia en homenaje a Otero Pedrayo: 85-101. Santiago. Secretariado de Publicaciones de la Universidad de Santiago de Compostela.

FRAGUAS FRAGUAS, A. 1999. La Galicia Insólita. Tradiciones gallegas. Sada. Ediciós do Castro. $7^{\text {a }}$ edición (ed or. A Coruña: Librigal, 1973).

GARCÍA ORO, J. 1977. Galicia en la Baja Edad Media. Iglesia, Señorio y Nobleza. Santiago. Bibliófilos Gallegos, Biblioteca de Galicia.

GARCÍA ORO, J. 1987. Galicia en los siglos XIV y XV. Galicia Histórica. A Coruña. Fundación Barrié de la Maza.

GARCÍA QUINTELA, M.V. 2003. Imágenes, Textos, Paisajes e Ideas: Los santuarios castreños en contexto. En Castiñeiras González, M.A. e Díez Platas, F. (ed.) 2003: Profano y pagano en el arte gallego. Semata, 14: 95-149. Santiago. Universidade de Santiago de Compostela.

GEERTZ, C. 1997. La interpretación de las culturas. Barcelona. Gedisa.

GIL MERINO, A. 1952. La Jurisdicción de la Puebla de Brollón en la segunda mitad del siglo XVIII. Notas acerca de la administración de sus bienes de Propios. Boletín de la Comisión de Monumentos de Lugo, 37-38. 73-79. 
GINZBURG, C. 2001. El queso y los gusanos. El cosmos según un molinero del siglo XVI. Barcelona: Ediciones Península.

GONZÁLEZ LOPO, D.L. 1997. As devocións relixiosas da Galicia moderna (séculos XVI-XVIII) En Galicia terra única. Galicia renace: 290-303. Santiago. Xunta de Galicia, Deputación de A Coruña.

GONZÁLEZ PÉREZ, C. 2003. Xaquín Lorenzo Fernández 'Xocas' (1907-1989). Unha vida dedicada á Nosa Cultura. Noia. Editorial Toxosoutos.

GONZÁLEZ REBOREDO, X.M. 1971. Folklore dos castros do Incio. Grial, 31. 21-29 Vigo.

GONZÁLEZ REBOREDO, X. M. 1971a. El folklore en los castros gallegos. Santiago de Compostela. USC.

GONZÁLEZ RUIBAL, A. 2003. Etnoarqueología de la Emigración. El fin del mundo preindustrial en Terra de Montes (Galicia). Pontevedra. Servicio de Publicacións da Deputación de Pontevedra.

GONZÁLEZ RUIBAL, A. 2003a. La experiencia del Otro. Una introducción a la Etnoarqueología. Akal Arqueología, 3. Madrid. Ediciones Akal.

GUITIÁN OJEA, F. 1974. Itinerario dé los suelos de Galicia. Santiago de Compostela. Servicio de Publicacións da Universidade de Santiago de Compostela.

GUREVICH, A. 1992. Historical anthropology of the Middle Ages. Ed. by Jana Howlett. Cambridge. Cambridge Polity Press.

LE GOFF, J. 1985. Lo maravilloso y lo cotidiano en el Occidente medieval. Barcelona. Gedisa.

LEMA SUÁREZ, X.Ma. 1977. Bamiro: un estudio do hábitat rural galego. Santiago. Colegio de Arquitectos de Galicia.

LE ROY LADURIE, E. 1981. Montaillou aldea occitana de 1294-1324. Taurus.

LÓPEZ CUEVILLAS, F. e LORENZO FERNÁNDEZ, X. 1930. Vila de Calvos. Santiago. SEG.

LÓPEZ CUEVILLAS, F., FERNÁNDEZ HERMIDA, V. e LORENZO FERNÁNDEZ, X. 1936. Parroquia de Velle. Santiago. Seminario de Estudios Galegos.

LÓPEZ GONZÁLEZ, L.F. 1993. Caurel-Valle de Quiroga. Estructura social y territorio. Tesis de Licenciatura inédita. Madrid. Universidad Complutense.

LUZÓN NOGUÉ, J.M. et alii. 1980. El Courel. Excavaciones Arqueológicas en España. $\mathrm{n}^{\circ} 110$. Madrid.

LLINARES GARCÍA, Ma . 1990. Os Mouros no Imaxinario popular galego. Santiago. USC.

LLINARES GARCÍA, Ma 1990a. Mouros, ánimas, demonios. Madrid. Akal.

LLINARES GARCÍA, Mª.M. e VÁZQUEZ VARELA, J.M. 1990. Señalización simbólica del territorio: la acción de los seres imaginarios. En Actas del Simposio Internacional de Antropoloxía Identidade e Territorio: 97 e ss. Santiago. Consello da Cultura Galega.

MADOZ, P. (Ed.) 1845-1850. Atlas de España y sus posesiones de Ultramar: notas estadísticas e históricas. Madrid.

MANDIANES CASTRO, M. 1984. Loureses. Antropoloxía dunha parroquia galega. Vigo. Galaxia.

Cuadernos de Estudios Gallegos, Tomo LII, Fascículo 118, Santiago 2005. (Págs. 117 - 172) 
MANDIANES CASTRO, M. 2003. O río do esquecemento. Identidade antropolóxica de Galicia. Vigo. Edicións Xerais.

MARTINÓN TORRES, M. 2001. Los megalitos de término. Crónica del valor territorial de los monumentos megalíticos a partir de las fuentes escritas. Trabajos de Prehistoria 58 (1): 95-108. Madrid. CSIC.

MIÑANO Y BEDOYA, S. 1827. Diccionario geográfico-estadístico de España y Portugal. Tomo II. Madrid. Imprenta de Pierart-Peralta.

PARCERO OUBIÑA, C. 2000. Tres para dos. Las formas del poblamiento en la Edad del Hierro del Noroeste ibérico. Trabajos de Prehistoria, 57: 75-95. Madrid. CSIC.

PARCERO OUBIÑA, C. 2001. La construcción del paisaje social en la Edad del Hierro del NW ibérico. Santiago. USC (edición en CD).

PENEDO ROMERO, M. y RODRÍGUEZ PUENTES, E. 1991. La Edad del Hierro: formas concretas del pasado fortificado. En Criado Boado, F. (dir.): Arqueología del Paisaje. El área BoceloFurelos entre los tiempos paleolíticos y medievales. pp 199-220. Arqueoloxia/Investigación, 6. Santiago. Xunta de Galicia.

PORTELA, E. e PALLARES, Ma .C. 1998. La villa, por dentro. Testimonios galaicos de los siglos X y XI. Studia Historica, $H^{a}$ Medieval, 16: 13-43. Salamanca. Ediciones Universidad de Salamanca.

RIElo CARBALlO, N. 1975. Voz Cereixa en Valiña Sampedro, E. et al. Inventario Artístico de Lugo y su provincia. Vol. 2. Madrid. Ministerio de Educación y Cultura.

RISCO, V. 1927. O castro de Caldelas. Santiago de Compostela. SEG.

RODRÍGUEZ CASAL, A.; EGUILETA FRANCO, J.Mª ; GÓMEZ NISTAL, C.; RAMOS ALVITE, E. y ROMANÍ FARIÑA, E. 1997: Metodología y primeras valoraciones de un proyecto interdisciplinar sobre el fenómeno tumular de la provincia de Lugo. En RODRÍGUEZ CASAL, A. (ed.): O Neolítico Atlántico e as orixes do Megalitismo: 521-536. Santiago. Universidade de Santiago de Compostela.

RODRÍGUEZ FERNÁNDEZ, T. 1994. El fin del mundo fortificado y la aparición de las aldeas abiertas. La evidencia del Centro-Oriente de Lugo (Samos y Sarria). Espacio, Tiempo y Forma, 7. 153-189. Madrid.

ROMERO MASIÁ, A. e POSE MESURA, X.M. 1987. Galicia nos textos clásicos. Monografías urxentes do museo, 3. Sada. Ediciós do Castro.

SAAVEDRA FERNÁNDEZ, P. 1994. La vida cotidiana en la Galicia del Antiguo Régimen. Barcelona. Crítica.

SAAVEDRA FERNÁNDEZ, P. 1996. Casa e Comunidade na Galicia interior, c. 1750-c. 1860. En Das casas de morada ó monte comunal: 17-74. Santiago. Xunta de Galicia.

SÁNCHEZ-PALENCIA, F.J.; FERNÁNDEZ-POSSE, M.D.; FERNÁNDEZ MANZANO, J. y OREJAS, A. 1996. La zona arqueológica de Las Médulas. León. Guía Arqueológica. Salamanca. Junta de Castilla y León. Instituto de Estudios Bercianos.

SANTOS ESTÉVEZ, M, PARCERO OUBIÑA. C. e CRIADO BOADO, F. 1997. De la arqueología simbólica del paisaje a la arqueología de los paisajes sagrados. Trabajos de Prehistoria, 54: 61-80. Madrid. CSIC. 
TABOADA CHIVITE, X. 1972. Etnografia galega. Cultura espiritual. Vigo. Galaxia.

TABOADA CHIVITE, X. 1980. Ritos y creencias gallegas. A Coruña. Sálvora.

VÁZQUEZ RODRÍGUEZ, X.M. 1997-98. Cerimonias de véspera. Os folións na Ribeira Sacra. Boletín do Museo Provincial de Lugo, VIII. Vol. 1. 215-308. Lugo

VILLOCH VÁZQUEZ, V. 2000. La Configuración social del espacio en las sociedades constructoras de túmulos en Galicia: estudios de emplazamiento tumular. Teses de Doutoramento da Universidade de Santiago de Compostela. Disco 2 (Humanidades e Ciencias Sociais). 